\title{
Microwave-Assisted Clean Synthesis of Amides via Aza-Wittig Reaction under Solvent-Free Condition
}

\author{
Murugan Sathishkumar, Sangaraiah Nagarajan, Poovan Shanmuga Velan, \\ Murugan Dinesh and Alagusundaram Ponnuswamy*
}

Department of Organic Chemistry, School of Chemistry, Madurai Kamaraj University, 625-021 Tamilnadu, India

\begin{abstract}
O acoplamento de fosfazenos com cloretos de acila ou anidridos carboxílicos mediado por microondas na presença de fosfito de etila foi realizado, resultando nas correspondentes amidas, de maneira limpa e com bons rendimentos. Ao contrário das metodologias anteriores, que empregam solventes clorados, benzeno (cancerígeno), etc, este protocolo é eco-amigável, rápido e simples.
\end{abstract}

A solvent-free microwave-assisted coupling of phosphazenes with acyl chlorides or carboxylic anhydrides in presence of triethylphosphite has been accomplished resulting in a clean synthesis of amides in good yields. Unlike the prevailing time-consuming solution phase methodologies employing chlorinated solvents, benzene (carcinogenic), etc, the present protocol is an eco friendly, rapid and simple approach.

Keywords: microwave, solution phase, solvent-free, amide, aza-wittig

\section{Introduction}

Amide is an ubiquitous functionality prevalent in natural products, peptides and potential drugs. ${ }^{1}$ In view of this, extensive research towards developing elegant protocols for amide bond formation is in progress wherein attempts are being continuously made to eradicate the difficulties and limitations enveloped with the prevailing methods.

Generally, the most relevant methodologies involve solution phase approach wherein the limitations associated with the polarity, refluxing temperature and the toxicity of the solvent/additives restrict their broad scope and question their eco-friendliness. Also, the components employed and formed as the by-products in the protocols play vital role in deciding the rate of the amide bond formation. Thus, all these aspects are to be considered in accomplishing timeconscious, eco-friendly protocols for amide bond formation.

In particular, the direct coupling of an amine with a carboxylic acid results in an acid-base reaction to form a stable salt following which the amide bond formation has to fight against adverse thermodynamics as the equilibrium lies on the side of hydrolysis rather than synthesis (Scheme 1).

Herein, azeotropic removal of water accumulated in the solution has been attempted ${ }^{2}$ for accomplishing an effective synthesis of amides. Alternatively, molecular sieves are added to the solution to trap the water and expedite the reaction.

On the other hand, the direct coupling of amines with carboxylic acids has been assisted by coupling reagents ${ }^{3}$ (Scheme 2). Apparently, use of excess of coupling reagents and their corrosive nature is hazardous to the environment.

Further, other approaches like aminocarbonylation ${ }^{4}$ of aryl halides with amines and catalysis 5 in amide bond formation in solvent medium are with limitations such as loading of metal carbonyls/catalyst for large scale preparation and difficulties in reactivation/reusability of deactivated catalyst which may preclude the scope of their applicability.

$$
\mathrm{R}^{1} \mathrm{NH}_{2}+\mathrm{R}^{2} \mathrm{COOH} \rightleftarrows \mathrm{R}^{1} \mathrm{NH}_{3}^{+} \mathrm{R}^{2} \mathrm{COO}^{-} \rightleftarrows \quad \mathrm{R}^{1} \mathrm{NHCOR}^{2}+\mathrm{H}_{2} \mathrm{O}
$$

Scheme 1. Direct coupling of amines with carboxylic acids.

*e-mail: ramradkrish@yahoo.co.in 


$$
\mathrm{R}^{1} \mathrm{NH}_{2}+\mathrm{R}^{2} \mathrm{COOH} \underset{\text { solvent }}{\stackrel{\text { coupling agent }}{\longrightarrow}} \mathrm{R}^{1} \mathrm{NHCOR}^{2}
$$

Scheme 2. Coupling of amines with carboxylic acids in presence of coupling agent.

An alternative solution phase protocol involves the coupling of Staudinger's phosphazenes, ${ }^{6}$ generated from phosphines and organic azides, with carboxylic acids ${ }^{7}$ (Scheme 3) or their derivatives ${ }^{8}$ to afford carboxamides. The limitations of this methodology are the usage of benzene (carcinogenic) or toluene as the solvent of choice, very long reaction times ${ }^{7}$ and solubility problems that arise with polar starting substrates. ${ }^{7}$

$$
\begin{aligned}
& \underset{\mathrm{R}^{1}-\mathrm{N}_{3}}{\mathrm{P}\left(\mathrm{R}^{3}\right)_{3}} \underset{-\mathrm{N}_{2}}{\longrightarrow} \mathrm{Ph}_{3} \mathrm{P}=\mathrm{NR}^{1} \stackrel{\mathrm{R}^{2}-\mathrm{COX}}{\text { phosphazene }} \begin{array}{c}
\text { solvents/ } \\
\text { longer time }
\end{array} \\
& \mathrm{X}=\mathrm{OH}, \mathrm{Cl} \text {, OCOR }
\end{aligned}
$$

Scheme 3. Coupling of Staudinger's phosphazene with carboxylic carboxylic acids or their derivatives.

The polarity of the substrates and reagents puts restriction to the number of useful solvents. Further, solvents employed may either enhance or retard the rate of the reaction performed in view of differing interactions. Above all, the above said preferred solvents restrict the possibility of exploring the effect of temperature on the rate of the amide bond formation. Sometimes, the reaction can not be studied at higher temperatures.

\section{Results and Discussion}

Microwave-assisted organic synthesis ${ }^{9}$ had replaced most of the time consuming conventional methodologies. Its applicability in amide bond formation has been scarcely studied. To the best of our knowledge, solvent-free coupling of phosphazenes with acid chlorides and anhydrides assisted by microwave has been never reported.

Hence, need for a better protocol avoiding the hazards to the environment becomes important. In this regard, we attempted the microwave-assisted aza-wittig coupling of the azides with acids in presence of triphenylphosphine under solvent-free condition. The reaction was fascinating in the sense, that the reaction was completed at $180{ }^{\circ} \mathrm{C}$ within $15 \mathrm{~min}$ with good yield of the amides. The above coupling in solvents have been reported $\mathrm{d}^{7}$ and noted by us to afford the amides in 3-72 $\mathrm{h}$. Thus the multifold increase in the rate under solvent-free condition has been apparently thought to be due to the close intimacy and collapsing of the reaction mixture. In spite of this advantage, the method was still time consuming due to the need for the isolation of the by-product viz. triphenylphosphine oxide from the reaction mixture. This tempted us to simplify the protocol by some appropriate modifications.

This has been accomplished by substituting the acyl chlorides or the anhydrides in the place of the carboxylic acids and triethylphosphite in the place of triphenylphosphine. This would result in (i) enhancing the electrophilicity of the acyl carbon resulting in accelerating the reaction at relatively lower temperature and (ii) formation of water soluble triethylphosphate as the by-product. Based on these presumptions the present work was attempted, the findings of which are presented below.

In a typical procedure (Scheme 4), a mixture of triethylphosphite $(1 \mathrm{mmol})$, organic azide $(1 \mathrm{mmol})$ and acid anhydride/acid chloride $(1.3 \mathrm{mmol})$ was irradiated with microwave for 15-20 min at the temperature indicated in Table 1 to afford the amide in good yield.

$$
\begin{aligned}
& \mathrm{R}^{1}-\mathrm{N}_{3}+\mathrm{P}(\mathrm{OEt})_{3}+\mathrm{R}^{2} \mathrm{COX} \underset{\text { solvent-free }}{\stackrel{\text { MW-20 min }}{\longrightarrow}} \mathrm{R}^{1} \mathrm{NHCOR}^{2} \\
& \mathrm{R}^{1}=\text { primary, secondary, aryl } \\
& \mathrm{X}=\mathrm{Cl} \text { or } \mathrm{OCOR}^{2}
\end{aligned}
$$

Scheme 4. Coupling of azides with carboxylic acid derivatives in the presence of triethyl phosphite.

\section{Conclusions}

In conclusion, the present study reports a solventfree microwave-assisted amide synthesis via coupling of phosphazenes with acyl chlorides or carboxylic anhydrides in presence of triethylphosphite. It is an eco-friendly, rapid and simple approach which avoids the limitations associated with time-consuming solution phase methodologies where benzene (carcinogenic), toluene and chlorinated solvents are preferably employed.

\section{Experimental}

All chemicals, reagents and solvents were of commercially high purity grade purchased from Avra Synthesis Pvt. Ltd. and Merck Ltd. India. Silica gel (60-120 mesh) was used for column chromatographic isolation and purification of the amides synthesized. Organic azides were prepared according to the literature procedures. Melting points were noted on electro-thermal apparatus and are uncorrected. ${ }^{1} \mathrm{H}$ NMR and ${ }^{13} \mathrm{C}$ NMR spectra were recorded in $\mathrm{CDCl}_{3}$ on Bruker Avance $300 \mathrm{MHz}$ spectrometer and the chemical shifts are reported as $\delta$ values in parts per million (ppm) 
Table 1. Microwave-assisted amide synthesis

\begin{tabular}{|c|c|c|c|c|c|c|}
\hline entry & azides & acid chloride/anhydride & time / min & $\mathrm{T} /\left({ }^{\circ} \mathrm{C}\right)$ & amide & yield / (\%) \\
\hline 1 & & & 15 & 100 & & 74 \\
\hline 2 & & & 15 & 100 & & 78 \\
\hline 3 & & & 15 & 100 & & 84 \\
\hline 4 & & & 15 & 100 & & 71 \\
\hline 5 & & & 15 & 100 & & 76 \\
\hline 6 & & & 20 & 100 & & 75 \\
\hline 7 & & & 20 & 100 & & 80 \\
\hline 8 & & & 20 & 100 & & 83 \\
\hline 9 & & & 20 & 100 & & 70 \\
\hline 10 & & & 20 & 100 & & 77 \\
\hline 11 & & & 15 & 150 & & 81 \\
\hline 12 & & & 15 & 150 & & 85 \\
\hline 13 & & & 15 & 150 & & 88 \\
\hline 14 & & & 15 & 150 & & 77 \\
\hline 15 & & & 15 & 150 & & 79 \\
\hline
\end{tabular}


relative to tetramethylsilane, with $J$ values in Hertz. The splitting patterns in ${ }^{1} \mathrm{H}$ NMR spectra are reported as follows: $\mathrm{s}=$ singlet; $\mathrm{d}=$ doublet; $\mathrm{t}$ = triplet; $\mathrm{q}=$ quartet; br $\mathrm{s}=$ broad singlet; br $\mathrm{d}=$ broad doublet; $\mathrm{m}=$ multiplet. ${ }^{13} \mathrm{C}$ NMR data are reported with the solvent peak $\left(\mathrm{CDCl}_{3}=77.0\right)$ as the internal standard. Elemental analyses were performed by CNRS (Vernaison, Lyon) and were in agreement with the calculated values within $\pm 0.4 \%$. Spectral data of known amides are given in supplementary section.

General procedure for the microwave-assisted synthesis of amides (Table 1, entry 1-15)

To an intimate mixture of triethylphosphite (1 equiv.) and organic azide (1 equiv.) in a microwave vial $(10 \mathrm{~mL})$ equipped with a magnetic stirring bar, acid anhydride/ acyl chloride (1.3 equiv.) was added in drops with stirring. Stirring was continued until liberation of nitrogen ceased and the reaction vessel was sealed with a septum. It was then placed into the cavity of a focused monomode microwave reactor (CEM Discover, benchmate) and operated for $15 \mathrm{~min}$ at $150{ }^{\circ} \mathrm{C}$ (temperature monitored by a built-in IR sensor). The reaction temperature was maintained by modulating the power level of the reactor. The reaction vessel was then cooled to room temperature and the residue was dissolved in ethyl acetate and washed repeatedly with water followed by saturated sodium bicarbonate solution to afford the amides as white solids.

$N$-(3-phenylcyclohex-2-enyl)acetamide (Table 1, entry 11) Yield $195 \mathrm{mg}(85 \%), \mathrm{mp} 118{ }^{\circ} \mathrm{C}$; IR $(\mathrm{KBr}) \mathrm{v}_{\max } / \mathrm{cm}^{-1}$ : 3445 (-NH), $1671(-\mathrm{C}=\mathrm{O}) ;{ }^{1} \mathrm{H}$ NMR $\left(300 \mathrm{MHz}, \mathrm{CDCl}_{3}\right)$ $\delta$ (ppm): 7.20-7.40 (m, 5H, ArH), 5.96 (pseudo triplet, $1 \mathrm{H}$, $\mathrm{C}=\mathrm{CH}), 5.60($ br d, $1 \mathrm{H}, J 7.5 \mathrm{~Hz},-\mathrm{NH}), 4.70($ br s, $1 \mathrm{H}$, CHN), 1.99 (s, 3H, $-\mathrm{COCH}_{3}$ ), 2.20-2.42 (m, 2H, alicyclic protons), 1.95-2.07 (m, 1H, alicyclic proton), 1.65-1.77 (m, $2 \mathrm{H}$, alicyclic protons), 1.39-1.53 (m, $1 \mathrm{H}$, alicyclic proton); ${ }^{13} \mathrm{C} \mathrm{NMR}\left(75 \mathrm{MHz}, \mathrm{CDCl}_{3}\right) \delta$ (ppm): 169.4, 148.1, 139.9, 138.7, 126.2, 125.0, 123.6, 45.5, 29.0, 27.1, 23.2, 20.1. Anal. calc. (\%) for $\mathrm{C}_{14} \mathrm{H}_{17} \mathrm{NO}$ : C, 78.10; H, 7.96; N, 6.51. Found (\%): C, 78.25; H, 7.95; N, 6.51.

N-(3-phenylcyclohex-2-enyl)propionamide (Table 1, entry 12)

Yield $195 \mathrm{mg}(85 \%), \mathrm{mp} 97{ }^{\circ} \mathrm{C}$; IR $(\mathrm{KBr}) \mathrm{v}_{\max } / \mathrm{cm}^{-1}$ : 3444 (-NH), $1682(-\mathrm{C}=\mathrm{O}) ;{ }^{1} \mathrm{H}$ NMR $\left(300 \mathrm{MHz}, \mathrm{CDCl}_{3}\right)$ $\delta$ (ppm): 7.20-7.50 (m, 5H, ArH), 5.96 (pseudo triplet, $1 \mathrm{H}$, $\mathrm{C}=\mathrm{CH}), 5.62(\mathrm{br} \mathrm{d}, 1 \mathrm{H}, J 6.9 \mathrm{~Hz},-\mathrm{NH}), 4.70(\mathrm{br} \mathrm{s}, 1 \mathrm{H}$, CHN), 2.21 (q, 2H, J 7.5 Hz, $\left.\mathrm{COCH}_{2}\right) 1.16(\mathrm{t}, 3 \mathrm{H}, J 7.5$ $\mathrm{Hz},-\mathrm{CH}_{3}$ ), 2.20-2.42 (m, 2H, alicyclic protons), 1.95-2.07 (m, 1H, alicyclic proton), 1.65-1.77 (m, 2H, alicyclic protons), $1.39-1.53\left(\mathrm{~m}, 1 \mathrm{H}\right.$, alicyclic proton); ${ }^{13} \mathrm{C} \mathrm{NMR}$ (75 MHz, $\mathrm{CDCl} 3) \delta$ (ppm): 173.0, 141.2, 140.1, 128.2, 127.3, 125.1, 124.6, 45.3, 29.8, 29.1, 27.1, 20.3, 9.8. Anal. calc. for $\mathrm{C}_{15} \mathrm{H}_{19} \mathrm{NO}$ : C, 78.56; H, 8.35; N, 6.11. Found: C, 78.46; H, 8.36; N, 6.10.

N-(3-phenylcyclohex-2-enyl)butyramide (Table 1, entry 13)

Yield $195 \mathrm{mg}(85 \%), \mathrm{mp} 128-129^{\circ} \mathrm{C}$; IR $(\mathrm{KBr}) v_{\max } / \mathrm{cm}^{-1}$ : 3447 (-NH), $1692(-\mathrm{C}=\mathrm{O}) ;{ }^{1} \mathrm{H}$ NMR $\left(300 \mathrm{MHz}, \mathrm{CDCl}_{3}\right) \delta$ (ppm): 7.25-7.39 (m, 5H, ArH), 5.96 (s, 1H, C=CH), 5.50 (br d, J 6.4 Hz, 1H, NH), 4.71 (br s, 1H, CHN), 2.36-2.40 (m, 2H), 2.16 (m, 2H), 1.95-1.97 (m, 1H, alicyclic protons), 1.81-1.83 (m, 2H, alicyclic protons), 1.68 (m, 2H, alicyclic protons), $1.55-1.57(\mathrm{~m}, 1 \mathrm{H}$, alicyclic protons), $0.95(\mathrm{t}, J$ $\left.14.7 \mathrm{~Hz}, 3 \mathrm{H}, \mathrm{CH}_{3}\right) .{ }^{13} \mathrm{C} \mathrm{NMR}(75 \mathrm{MHz}, \mathrm{CDCl} 3) \delta(\mathrm{ppm})$ : 172.9, 141.2, 140.2, 128.2, 127.3, 125.1, 124.6, 45.3, 29.8, 29.1, 27.2, 20.3, 18.3, 9.8. Anal. calc. for $\mathrm{C}_{16} \mathrm{H}_{21} \mathrm{NO}$ : $\mathrm{C}$, 78.97; H, 8.70; N, 5.76. Found: C, 78.88; H, 8.72; N, 5.77.

$N$-(3-phenylcyclohex-2-enyl)benzamide (Table 1, entry 15) Yield $220 \mathrm{mg}(79 \%), \mathrm{mp} 154{ }^{\circ} \mathrm{C}$; IR (KBr) $v_{\max } / \mathrm{cm}^{-1}$ : $3451(-\mathrm{NH}), 1670(-\mathrm{C}=\mathrm{O}) ;{ }^{1} \mathrm{H} \mathrm{NMR}\left(300 \mathrm{MHz}, \mathrm{CDCl}_{3}\right)$ $\delta$ (ppm): 7.29-7.75 (10H, m, ArH), 6.00 (br s, 1H, C=CH), 5.60 (br d, $1 \mathrm{H}, J 8.4 \mathrm{~Hz}, \mathrm{NH}$ ), 4.60 (br s, $1 \mathrm{H}, \mathrm{CHN}$ ), 2.202.42 ( $\mathrm{m}, 2 \mathrm{H}$, alicyclic protons), 1.95-2.07 (m, $1 \mathrm{H}$, alicyclic proton), $1.65-1.77$ (m, 2H, alicyclic protons), 1.39-1.53 (m, 1H, alicyclic proton); ${ }^{13} \mathrm{C} \mathrm{NMR}\left(75 \mathrm{MHz}, \mathrm{CDCl}_{3}\right) \delta$ (ppm): 166.7, 148.2, 140.4, 138.6, 134.7, 131.3, 128.4, 126.9, 126.4, 125.1, 123.6, 45.0, 29.1, 27.2, 20.4. Anal. calc. for $\mathrm{C}_{19} \mathrm{H}_{19} \mathrm{NO}$ : C, 82.28; H, 6.90; N, 4.05. Found: C, 82.13; H, 6.91; N, 5.06.

\section{Supplementary Information}

The spectroscopic ${ }^{1} \mathrm{H}$ NMR, ${ }^{13} \mathrm{C}$ NMR, IR data as well as the HRMS of selected compounds are available free of charge at http://jbcs.sbq.org.br as PDF file.

\section{Acknowledgments}

The authors, M. S, S. N and P. S acknowledge their grateful thanks to UGC for the sanction of UGC-JRF meritorious fellowship and IRHPA, DST for providing $300 \mathrm{MHz}$ NMR instrument for recording the NMR spectra for the compounds synthesized.

\section{References}

1. Hudson, D.; J. Org. Chem. 1988, 53, 617; Beckwith, A. L. J. In The Chemistry of Amides: Synthesis of Amides; Zabicky, J., ed.; Interscience: New York, 1970, p. 96; Trost, B. M.; Fleming, I. 
In Comprehensive Organic Synthesis; Winterfeld, E., ed.; Pergamon: Oxford, 1991, Vol. 6; Ghose, A. K.; Viswanadhan, V. N.; Vendol, J. J.; J. Comb. Chem. 1999, 1, 55.

2. Cossy, J.; Pale-Grosdemange, C.; Tetrahedron Lett. 1989, 30, 2771.

3. Heal, W.; Thompson, M. J.; Mutter, R.; Cope, H.; Louth, J. C.; Chen. B.; J. Med. Chem. 2007, 50, 1347; Dunn, P. J.; Galvin, S.; Hettenbach, K.; Green Chem. 2004, 6, 43; Petersson, M. J.; Marchal, C.; Loughlin, W. A.; Jenlins, I. D.; Healy, P. C.; Almesaker, A.; Tetrahedron 2007, 63, 1395; Kadam, S. T.; Kim, S. S.; Synthesis 2008, 2, 267.

4. Letavic, M. A.; Ly, K. S.; Tetrahedron Lett. 2007, 48, 2339; Lagerlund, O.; Mette, L.; Mantel, H.; Larhed, M.; Tetrahedron 2009, 65, 7646.

5. Narender, N.; Srinivasu, P.; Kulkarni, S. J.; Raghavan, K. V.; Green Chem. 2000, 2, 104; Bures, J.; Martin, M.; Urpi, F.; Vilarrasa, J; J. Org. Chem. 2009, 74, 2203; Luque, R.; Budarin, V.; Clark, J. H.; Macquarrie, D. J.; Green Chem. 2009, 11, 459;
Maki, T.; Ishihara, K.; Yamamoto, H.; Tetrahedron 2007, 63, 8645.

6. Staudinger, H.; Meyer, J.; Helv. Chim. Acta 1919, 2, 635; Gololobov, Yu. G.; Zhmurova, I. N.; Kasukhin, L. F.; Tetrahedron 1981, 37, 437; Gololobov, Yu. G.; Kasukhin, L. F.; Tetrahedron 1992, 48, 1353.

7. Garica, J.; Urpi, F.; Vilarrasa, J.; Tetrahedron Lett. 1984, 25, 4841; Kovacs, L.; Osz, E.; Domokos, V.; Holzer, W.; Gyorgydesk, Z.; Tetrahedron 2001, 57, 4609; Malkinson, J. P.; Falconer, R. A.; Toth, I. J.; J. Org. Chem. 2000, 65, 5249; Urpi, F.; Vilarrasa, J.; Tetrahedron Lett. 1986, 27, 4623.

8. Shalev, D. E.; Chiacchiera, S. M.; Radkowsky, A. E.; Kosower, E. M.; J .Org. Chem. 1996, 61, 1689; Bosch, I.; Gonzalez, A.; Urpi, F.; Vilarrasa, J.; J. Org. Chem. 1996, 61, 5638.

9. Polshettiwar, V.; Varma, R. S.; Acc. Chem. Res. 2008, 41, 629.

Submitted: May 31, 2011 Published online: September 1, 2011 


\title{
Microwave-Assisted Clean Synthesis of Amides via Aza-Wittig Reaction under Solvent-Free Condition
}

\author{
Murugan Sathishkumar, Sangaraiah Nagarajan, Poovan Shanmuga Velan, \\ Murugan Dinesh and Alagusundaram Ponnuswamy*
}

Department of Organic Chemistry, School of Chemistry, Madurai Kamaraj University, 625-021 Tamilnadu, India

\section{Experimental}

\section{General}

All chemicals, reagents and solvents were of commercially high purity grade purchased from Avra Synthesis Pvt. Ltd. and Merck Ltd. India. Silica gel (60120 mesh) was used for column chromatographic isolation and purification of the amides synthesized. Organic azides used in the investigation were prepared according to the literature procedures. Melting points were noted on electro-thermal apparatus and are uncorrected. ${ }^{1} \mathrm{H}$ NMR and ${ }^{13} \mathrm{C}$ NMR spectra were recorded in $\mathrm{CDCl}_{3}$ on Bruker Avance $300 \mathrm{MHz}$ spectrometer and the chemical shifts are reported as $\delta$ values in parts per million (ppm) relative to tetramethylsilane, with $J$ values in Hertz. The splitting patterns in ${ }^{1} \mathrm{H}$ NMR spectra are reported as follows: $\mathrm{s}=$ singlet; $\mathrm{d}=$ doublet; $\mathrm{t}=$ triplet; $\mathrm{q}=$ quartet; $\mathrm{br} \mathrm{s}=$ broad singlet; br $\mathrm{d}=$ broad doublet; $\mathrm{m}=$ multiplet. ${ }^{13} \mathrm{C}$ NMR data are reported with the solvent peak $\left(\mathrm{CDCl}_{3}=77.0\right)$ as the internal standard. Elemental analyses were performed by CNRS (Vernaison, Lyon) and were in agreement with the calculated values within $\pm 0.4 \%$.

Experimental procedure for the preparation of azides used in the synthesis of amides

\section{Benzyl azide ${ }^{l}$}

To a stirred solution of the benzyl bromide $(1 \mathrm{~g}$, $5.84 \mathrm{mmol})$ in water/acetone mixture $(1: 4 \mathrm{v} / \mathrm{v}, 10 \mathrm{~mL})$, sodium azide $(0.57 \mathrm{~g}, 8.77 \mathrm{mmol})$ was added. The resulting suspension was stirred at room temperature for $24 \mathrm{~h}$. Dichloromethane was added to the mixture and the organic layer was separated. The aqueous layer was extracted with dichloromethane $(3 \times 10 \mathrm{~mL})$ and the combined organic

*e-mail: ramradkrish@yahoo.co.in layers were dried over anhydrous magnesium sulphate. Solvent was removed under reduced pressure, and the azide was obtained in quantitative yield sufficiently pure to use without further work up.

\section{1-Azido-3-phenyl-2-cyclohex-2-ene ${ }^{2}$}

To $20 \%$ ethanolic potassium hydroxide $(10 \mathrm{~mL})$, 1a-azido-2a-iodo-1e-phenylcyclohexane $(1.0 \mathrm{~g}, 3.0 \mathrm{mmol})$ was added and the mixture refluxed for $1 \mathrm{~h}$ in water bath. Then the mixture after cooling to room temperature was added to excess water and extracted with ether $(3 \times 20 \mathrm{~mL})$. The organic extract was washed repeatedly with water, dried over anhydrous magnesium sulphate to give the allyl azide contaminated with 1-phenylcyclohexene. Column chromatographic purification on silica with pet ether/ethyl acetate as the eluant afford 1-azido-3-phenyl-2-cyclohex2-ene in good yield.

\section{Phenyl azide ${ }^{3}$}

These azides were prepared by the diazotization procedure similar to that used for the preparation of iodobenzene from aminobenzene by diazotization followed by treatment of aqueous potassium iodide at low temperature. Herein, by the same procedure diazotized solution of aminobenzene and 1-amino-4-bromobenzene were treated with aqueous sodium azide to afford the corresponding organic azides, respectively, which was used without further purification for the synthesis of amides in our investigation.

$N$-(3-phenylcyclohex-2-enyl)acetamide (Table 1, entry 11)

To an intimate mixture of triethylphosphite $(166 \mathrm{mg}$, $1 \mathrm{mmol})$ and 1-azido-3-phenyl-2-cyclohexene $(200 \mathrm{mg}$, $1 \mathrm{mmol})$ in a micro-wave vial $(10 \mathrm{~mL})$ equipped with a magnetic stirring bar, acetic anhydride (134 mg, $1.3 \mathrm{mmol}$ ) was added in drops while stirring. Stirring was continued until liberation of nitrogen ceased and the reaction vessel 
was sealed with a septum. It was then placed into the cavity of a focused monomode micro-wave reactor (CEM Discover, benchmate) and operated for $15 \mathrm{~min}$ at $150{ }^{\circ} \mathrm{C}$ (temperature monitored by a built-in IR sensor). The reaction temperature was maintained by modulating the power level of the reactor. The reaction vessel was then cooled to room temperature and the residue was dissolved in ethylacetate and washed repeatedly with water followed by saturated sodium bicarbonate solution to afford the amide as white solid. Experimental $85 \%$, mp $118^{\circ} \mathrm{C}$; IR $(\mathrm{KBr})$ $v_{\text {max }} / \mathrm{cm}^{-1}: 3445(-\mathrm{NH}), 1671(-\mathrm{C}=\mathrm{O})$; ${ }^{1} \mathrm{H}$ NMR $(300 \mathrm{MHz}$, $\left.\mathrm{CDCl}_{3}\right) \delta$ (ppm): 7.20-7.40 (m, 5H, ArH), 5.96 (pseudo triplet, $1 \mathrm{H}, \mathrm{C}=\mathrm{CH}), 5.60(\mathrm{br} \mathrm{d}, 1 \mathrm{H}, J 7.5 \mathrm{~Hz},-\mathrm{NH}), 4.70$ (br s, $1 \mathrm{H}, \mathrm{CHN}), 1.99\left(\mathrm{~s}, 3 \mathrm{H},-\mathrm{COCH}_{3}\right), 2.20-2.42(\mathrm{~m}, 2 \mathrm{H}$, alicyclic protons), 1.95-2.07 (m, $1 \mathrm{H}$, alicyclic proton), 1.65$1.77(\mathrm{~m}, 2 \mathrm{H}$, alicyclic protons), 1.39-1.53 (m, 1H, alicyclic proton); ${ }^{13} \mathrm{C}$ NMR (75 MHz, $\left.\mathrm{CDCl}_{3}\right) \delta$ (ppm): 169.4, 148.1, 139.9, 138.7, 126.2, 125.0, 123.6, 45.5, 29.0, 27.1, 23.2, 20.1. Anal. calc. (\%) for $\mathrm{C}_{14} \mathrm{H}_{17} \mathrm{NO}: \mathrm{C}, 78.10 ; \mathrm{H}, 7.96 ; \mathrm{N}$, 6.51. Found (\%) C, 78.25; H, 7.95; N, 6.51 .

\section{N-(3-phenylcyclohex-2-enyl)propionamide (Table 1, entry} 12)

The reaction mixture obtained from triethylphosphite (166 mg, $1 \mathrm{mmol}$ ), 1-azido-3-phenyl-2-cyclohexene $(200 \mathrm{mg}, 1 \mathrm{mmol})$ and propionic anhydride $(170 \mathrm{mg}$, $1.3 \mathrm{mmol}$ ) was irradiated with microwave for the indicated time and temperature in Table 1 (vide supra); then, it was cooled to room temperature and the residue was dissolved in ethylacetate and washed repeatedly with water followed by saturated sodium bicarbonate solution to afford the amide as white solid. Yield $85 \%, \mathrm{mp} 97{ }^{\circ} \mathrm{C}$; IR (KBr) $v_{\max } / \mathrm{cm}^{-1}$ : $3444(-\mathrm{NH}), 1682(-\mathrm{C}=\mathrm{O})$; ${ }^{1} \mathrm{H}$ NMR $\left(300 \mathrm{MHz}, \mathrm{CDCl}_{3}\right)$ $\delta$ (ppm): 7.20-7.50 (m, 5H, ArH), 5.96 (pseudo triplet, $1 \mathrm{H}, \mathrm{C}=\mathrm{CH}), 5.62(\mathrm{br} \mathrm{d}, 1 \mathrm{H}, J 6.9 \mathrm{~Hz},-\mathrm{NH}), 4.70$ (br s, $1 \mathrm{H}, \mathrm{CHN}), 2.21\left(\mathrm{q}, 2 \mathrm{H}, J 7.5 \mathrm{~Hz}, \mathrm{COCH}_{2}\right) 1.16(\mathrm{t}, 3 \mathrm{H}$, $\left.J 7.5 \mathrm{~Hz},-\mathrm{CH}_{3}\right), 2.20-2.42$ (m, $2 \mathrm{H}$, alicyclic protons), 1.95-2.07 $(\mathrm{m}, 1 \mathrm{H}$, alicyclic proton), $1.65-1.77(\mathrm{~m}, 2 \mathrm{H}$, alicyclic protons), $1.39-1.53(\mathrm{~m}, 1 \mathrm{H}$, alicyclic proton); ${ }^{13} \mathrm{C}$ NMR (75 MHz, CDCl3) $\delta$ (ppm): 173.0, 141.2, 140.1, 128.2, 127.3, 125.1, 124.6, 45.3, 29.8, 29.1, 27.1, 20.3, 9.8. Anal. calc. for $\mathrm{C}_{15} \mathrm{H}_{19} \mathrm{NO}$ : C, 78.56; H, 8.35; N, 6.11. Found: C, 78.46; H, 8.36; N, 6.10.

\section{N-(3-phenylcyclohex-2-enyl)butyramide (Table 1, entry 13)}

The reaction mixture obtained from triethylphosphite (166 mg, $1 \mathrm{mmol}$ ), 1-azido-3-phenyl-2-cyclohexene (200 mg, $1 \mathrm{mmol})$ and butyric anhydride $(200 \mathrm{mg}$, $1.3 \mathrm{mmol}$ ) was irradiated with microwave for the indicated time and temperature in Table 1 (vide supra); then, it was cooled to room temperature and the residue was dissolved in ethylacetate and washed repeatedly with water followed by saturated sodium bicarbonate solution to afford the amide as white solid. Experimental $85 \%, \mathrm{mp} 128-129^{\circ} \mathrm{C}$; IR $(\mathrm{KBr}) v_{\max } / \mathrm{cm}^{-1}$ : $3447(-\mathrm{NH}), 1692(-\mathrm{C}=\mathrm{O}) ;{ }^{1} \mathrm{H}$ NMR $\left(300 \mathrm{MHz}, \mathrm{CDCl}_{3}\right)$ $\delta$ (ppm): 7.25-7.39 (m, 5H, ArH), $5.96(\mathrm{~s}, 1 \mathrm{H}, \mathrm{C}=\mathrm{CH}), 5.50$ (br d, J $6.4 \mathrm{~Hz}, 1 \mathrm{H}, \mathrm{NH}$ ), 4.71 (br s, 1H, CHN), 2.36-2.40 $(\mathrm{m}, 2 \mathrm{H}), 2.16(\mathrm{~m}, 2 \mathrm{H}), 1.95-1.97$ ( $\mathrm{m}, 1 \mathrm{H}$, alicyclic protons), 1.81-1.83 (m, $2 \mathrm{H}$, alicyclic protons), $1.68(\mathrm{~m}, 2 \mathrm{H}$, alicyclic protons), $1.55-1.57(\mathrm{~m}, 1 \mathrm{H}$, alicyclic protons), $0.95(\mathrm{t}$, $\left.J 14.7 \mathrm{~Hz}, 3 \mathrm{H}, \mathrm{CH}_{3}\right) \cdot{ }^{13} \mathrm{C}$ NMR $(75 \mathrm{MHz}, \mathrm{CDCl} 3) \delta(\mathrm{ppm})$ : 172.9, 141.2, 140.2, 128.2, 127.3, 125.1, 124.6, 45.3, 29.8, 29.1, 27.2, 20.3, 18.3, 9.8. Anal. calc. for $\mathrm{C}_{16} \mathrm{H}_{21} \mathrm{NO}$ : C, 78.97; H, 8.70; N, 5.76. Found: C, 78.88; H, 8.72; N, 5.77.

\section{$N$-(3-phenylcyclohex-2-enyl)acetamide (entry 14)}

The reaction mixture obtained from triethylphosphite (166 mg, $1 \mathrm{mmol}$ ), 1-azido-3-phenyl-2-cyclo-hexene (200 mg, $1 \mathrm{mmol})$ and acetyl chloride $(110 \mathrm{mg}, 1.3 \mathrm{mmol})$ was irradiated with microwave for the indicated time and temperature in Table 1 (vide supra); then, it was cooled to room temperature and the residue was dissolved in ethylacetate and washed repeatedly with water followed by saturated sodium bicarbonate solution to afford the amide as white solid. Yield: $166 \mathrm{mg}$ (77\%).

\section{$N$-(3-phenylcyclohex-2-enyl)benzamide (entry 15)}

The reaction mixture obtained from triethylphosphite (166 mg, $1 \mathrm{mmol}$ ), 1-azido-3-phenyl-2-cyclo-hexene (200 mg, 1mmol) and benzoyl chloride (185 mg, $1.3 \mathrm{mmol})$ was irradiated with microwave for the indicated time and temperature in Table 1 (vide supra); then, it was cooled to room temperature and the residue was dissolved in ethylacetate and washed repeatedly with water followed by saturated sodium bicarbonate solution to afford the amide as white solid. Yield $79 \%$, mp $154{ }^{\circ} \mathrm{C}$; IR (KBr) $v_{\text {max }} / \mathrm{cm}^{-1}: 3451(-\mathrm{NH}), 1670(-\mathrm{C}=\mathrm{O}) ;{ }^{1} \mathrm{H}$ NMR $(300 \mathrm{MHz}$, $\left.\mathrm{CDCl}_{3}\right) \delta$ (ppm): 7.29-7.75 (10H, m, ArH), 6.00 (br s, $1 \mathrm{H}, \mathrm{C}=\mathrm{CH}), 5.60(\mathrm{br} \mathrm{d}, 1 \mathrm{H}, J 8.4 \mathrm{~Hz}, \mathrm{NH}), 4.60(\mathrm{br} \mathrm{s}, 1 \mathrm{H}$, CHN), 2.20-2.42 (m, 2H, alicyclic protons), 1.95-2.07 (m, $1 \mathrm{H}$, alicyclic proton), $1.65-1.77$ (m, $2 \mathrm{H}$, alicyclic protons), 1.39-1.53 (m, $1 \mathrm{H}$, alicyclic proton); ${ }^{13} \mathrm{C}$ NMR $(75 \mathrm{MHz}$, $\left.\mathrm{CDCl}_{3}\right) \delta(\mathrm{ppm}): 166.7,148.2,140.4,138.6,134.7,131.3$, 128.4, 126.9, 126.4, 125.1, 123.6, 45.0, 29.1, 27.2, 20.4. Anal. calc. for $\mathrm{C}_{19} \mathrm{H}_{19} \mathrm{NO}$ : C, 82.28; H, 6.90; N, 4.05. Found: C, 82.13; H, 6.91; N, 5.06.

\section{$N$-benzylacetamide (Table 1, entry 1)}

Yield 74\%, mp $58{ }^{\circ} \mathrm{C}$ (Lit. 59-60 ${ }^{\circ} \mathrm{C}$ ) $;{ }^{4} \mathrm{H}$ NMR $\left(300 \mathrm{MHz}, \mathrm{CDCl}_{3}\right) \delta$ (ppm): 7.33-7.36 (m, 5H, ArH), 5.10 (s, $\left.2 \mathrm{H}, \mathrm{CH}_{2} \mathrm{~N}\right), 2.09\left(\mathrm{~s}, 3 \mathrm{H}, \mathrm{CH}_{3}\right)$. 
N-benzylpropionamide (Table 1, entry 2)

Yield 78\%; mp $47{ }^{\circ} \mathrm{C}$ (Lit.48-49 ${ }^{\circ} \mathrm{C}$ ) $;{ }^{5} \mathrm{H}$ NMR (300 MHz, $\left.\mathrm{CDCl}_{3}\right) \delta$ (ppm) 7.12-7.33 (m, 5H, ArH), 4.99 (s, 2H, $\left.\mathrm{CH}_{2} \mathrm{~N}\right), 2.75\left(\mathrm{q}, J 7.2 \mathrm{~Hz}, 2 \mathrm{H}, \mathrm{CH}_{2}\right), 1.14$ (t, J 7.2 $\mathrm{Hz}, 3 \mathrm{H}, \mathrm{CH}_{3}$ ).

$N$-benzylbutyramide 6 (Table 1, entry 3)

Yield 84\%; ${ }^{1} \mathrm{H}$ NMR $\left(300 \mathrm{MHz}, \mathrm{CDCl}_{3}\right) \delta$ (ppm) 7.12-7.35 (m, 5H, $\mathrm{ArH}), 4.98\left(\mathrm{~s}, 2 \mathrm{H}, \mathrm{CH}_{2}-\mathrm{N}\right), 2.69(\mathrm{t}$, $J 7.2 \mathrm{~Hz}, 2 \mathrm{H}, \mathrm{CH}_{2}$ ), 1.69 (sextet, $J 7.2 \mathrm{~Hz}, 2 \mathrm{H}, \mathrm{CH}_{2}$ ), 0.93 (t, $J 7.2 \mathrm{~Hz}, 3 \mathrm{H}, \mathrm{CH}_{3}$ ).

\section{N-benzylbenzamide (Table 1, entry 5)}

Yield 76\%; mp $103{ }^{\circ} \mathrm{C}$ (Lit.103-104 ${ }^{\circ} \mathrm{C}$ ) $;{ }^{5} \mathrm{H}$ NMR $\left(300 \mathrm{MHz}, \mathrm{CDCl}_{3}\right) \delta(\mathrm{ppm}) 7.32-8.18(10 \mathrm{H}, \mathrm{m}, \mathrm{ArH})$, 6.61(1H, br s, NH), $4.65\left(2 \mathrm{H}, \mathrm{d}, J 5.7 \mathrm{~Hz}, \mathrm{CH}_{2}-\mathrm{N}\right)$.

$N$-phenylacetamide (Table 1, entry 6)

Yield 75\%; mp $115{ }^{\circ} \mathrm{C}$ (Lit.115-116 ${ }^{\circ} \mathrm{C}$ ); $7^{7} \mathrm{H}$ NMR $\left(300 \mathrm{MHz}, \mathrm{CDCl}_{3}\right) \delta$ (ppm) 7.08-7.50 (5H, m, ArH), 2.18 $\left(\mathrm{s}, 3 \mathrm{H}, \mathrm{CH}_{3}\right)$.

N-phenylpropionamide (Table 1, entry 7)

Yield 80\%; mp $105{ }^{\circ} \mathrm{C}$ (Lit. 105-106 ${ }^{\circ} \mathrm{C}$ ) $;{ }^{7} \mathrm{H}$ NMR (300 MHz, $\left.\mathrm{CDCl}_{3}\right) \delta(\mathrm{ppm})$ 7.06-7.56 (m, 5H, ArH), 2.38 $\left(\mathrm{q}, J 7.5 \mathrm{~Hz}, 2 \mathrm{H}, \mathrm{CH}_{2}\right), 1.24\left(\mathrm{t}, J 7.5 \mathrm{~Hz}, 3 \mathrm{H}, \mathrm{CH}_{3}\right)$.
N-phenylbutyramide 6 (Table 1, entry 8)

Yield 83\%; ${ }^{1} \mathrm{H}$ NMR $\left(300 \mathrm{MHz}, \mathrm{CDCl}_{3}\right) \delta(\mathrm{ppm})$ 7.06-7.52 (m, 5H, ArH), 2.32 (t, J 7.5Hz, 2H, $\left.\mathrm{CH}_{2}\right), 1.75$ (sextet, $\left.J 7.5 \mathrm{~Hz}, 2 \mathrm{H}, \mathrm{CH}_{2}\right), 0.99\left(\mathrm{t}, J 7.5 \mathrm{~Hz}, 3 \mathrm{H}, \mathrm{CH}_{3}\right.$ ).

N-phenylbenzamide (Table 1, entry 10)

Yield 77\%; mp $164{ }^{\circ} \mathrm{C}$ (Lit. $162^{\circ} \mathrm{C}$ ); ${ }^{5}{ }^{1} \mathrm{H}$ NMR $\left(300 \mathrm{MHz}, \mathrm{CDCl}_{3}\right) \delta$ (ppm) 7.15-7.88 (m, 10H, $\mathrm{ArH}$ ).

\section{References}

1. Campbell-Verduyn, L. S.; Mirfeizi, L.; Dierckx, R. A.; Elsinga, P. H.; Feringa, B. L.; Chem. Commun. 2009, 2139.

2. Crotti, P.; Chinni, M.; Uccello-Barretta, G.; Macchia, F.; J. Org. Chem. 1989, 54, 4525.

3. Furniss, B. S.; Hannaford, A. J.; Rogers, V.; Smith, P. W. G.; Tatchell, A. R.; Vogel's Textbook for Practical Organic Chemistry, $4^{\text {th }}$ ed.; ELBS Longman: Harlow, Essex, 1978.

4. Shi, M.; Cui, S, C.; Synth. Commun. 2005, 35, 2847.

5. Saito, Y.; Ouchi, H.; Takahata, H.; Tetrahedron 2008, 64, 11129.

6. Allen, L. C.; Davulcu, S.; William, J. M. J.; Org. Lett. 2010, 12, 5096.

7. Eshghi, H.; Gordi, Z.; Synth.Commun. 2003, 33, 2971.

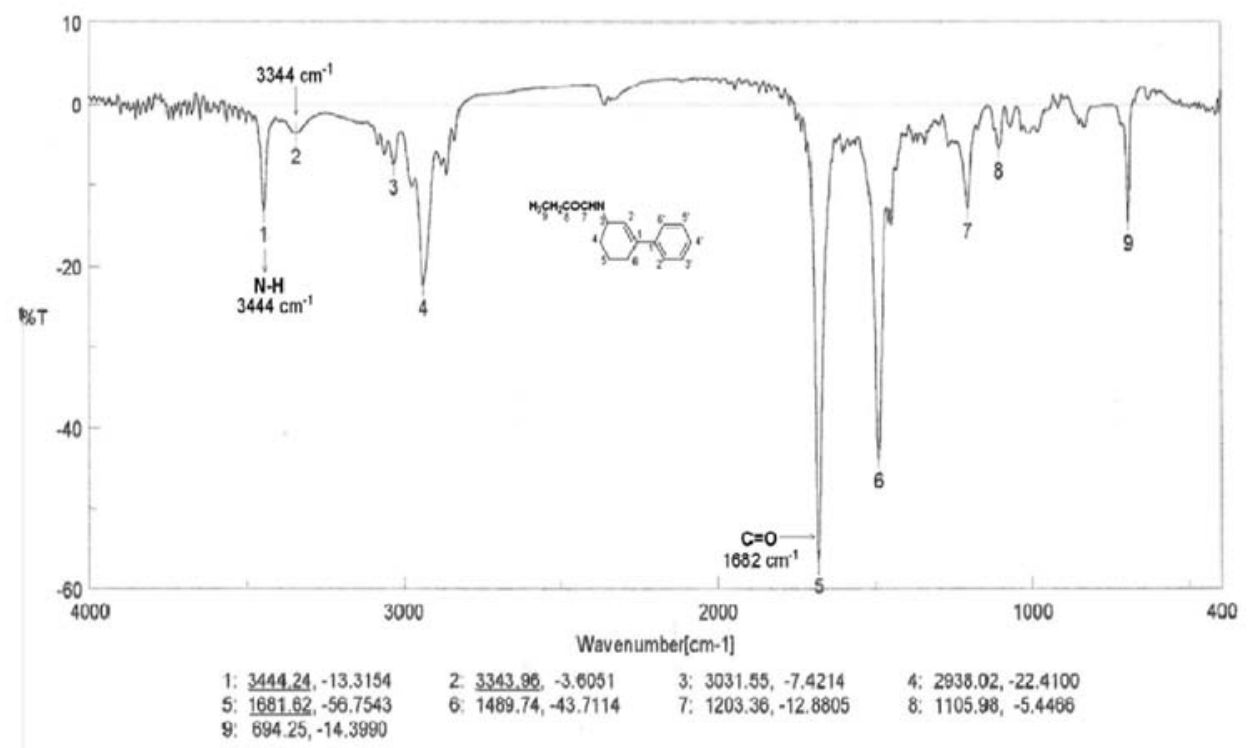

Figure S1. IR spectrum of $N$-(3-phenylcyclohex-2-enyl)propionamide (Table 1, entry 12). 
<smiles>CCC(=O)NC1C=C(c2ccccc2)CCC1</smiles>

\section{Elemental Composition Report}

\section{Single Mass Analysis}

Tolerance $=200.0 \mathrm{mDa} /$ DBE: $\min =-1.5, \max =50.0$

Isotope cluster parameters: Separation $=1.0$ Abundance $=1.0 \%$

Monoisotopic Mass, Odd and Even Electron lons

2 formula(e) evaluated with 1 results within limits (all results (up to 1000) for each mass)

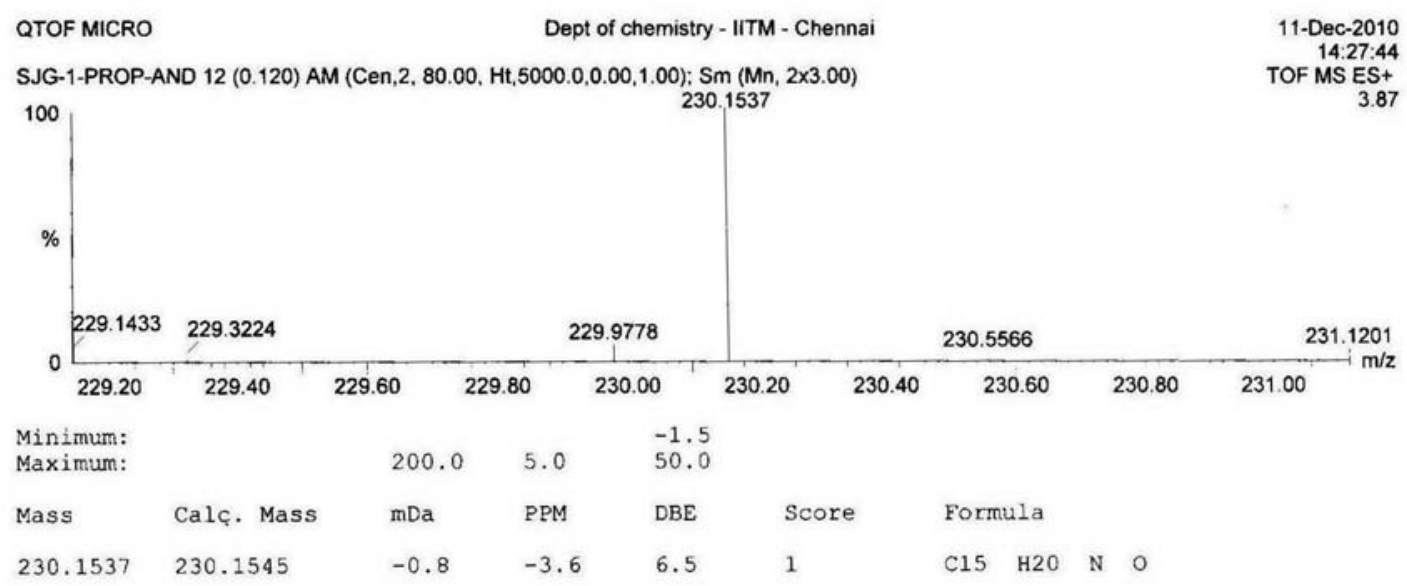

Figure S2. HRMS of $N$-(3-phenylcyclohex-2-enyl)propionamide (Table 1, entry 12). 
<smiles>CCC(=O)NC1C=C(c2ccccc2)CCC1</smiles>
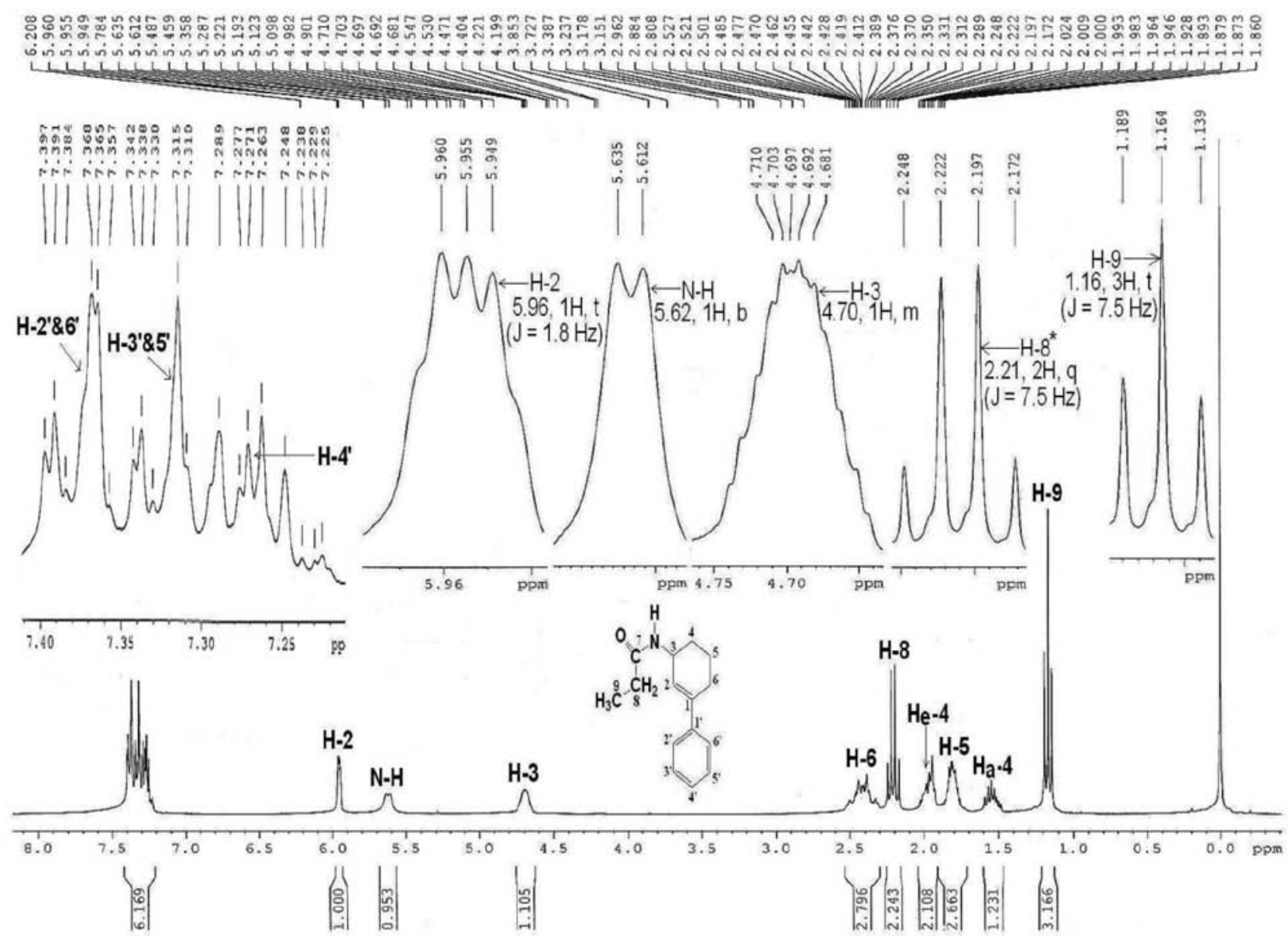

Figure S3. ${ }^{1} \mathrm{H}$ NMR (300 MHz, $\mathrm{CDCl}_{3}$ ) of $\mathrm{N}$-(3-phenylcyclohex-2-enyl)propionamide (Table 1, entry 12 ). 
<smiles>CCC(=O)NC1C=C(c2ccccc2)CCC1</smiles>

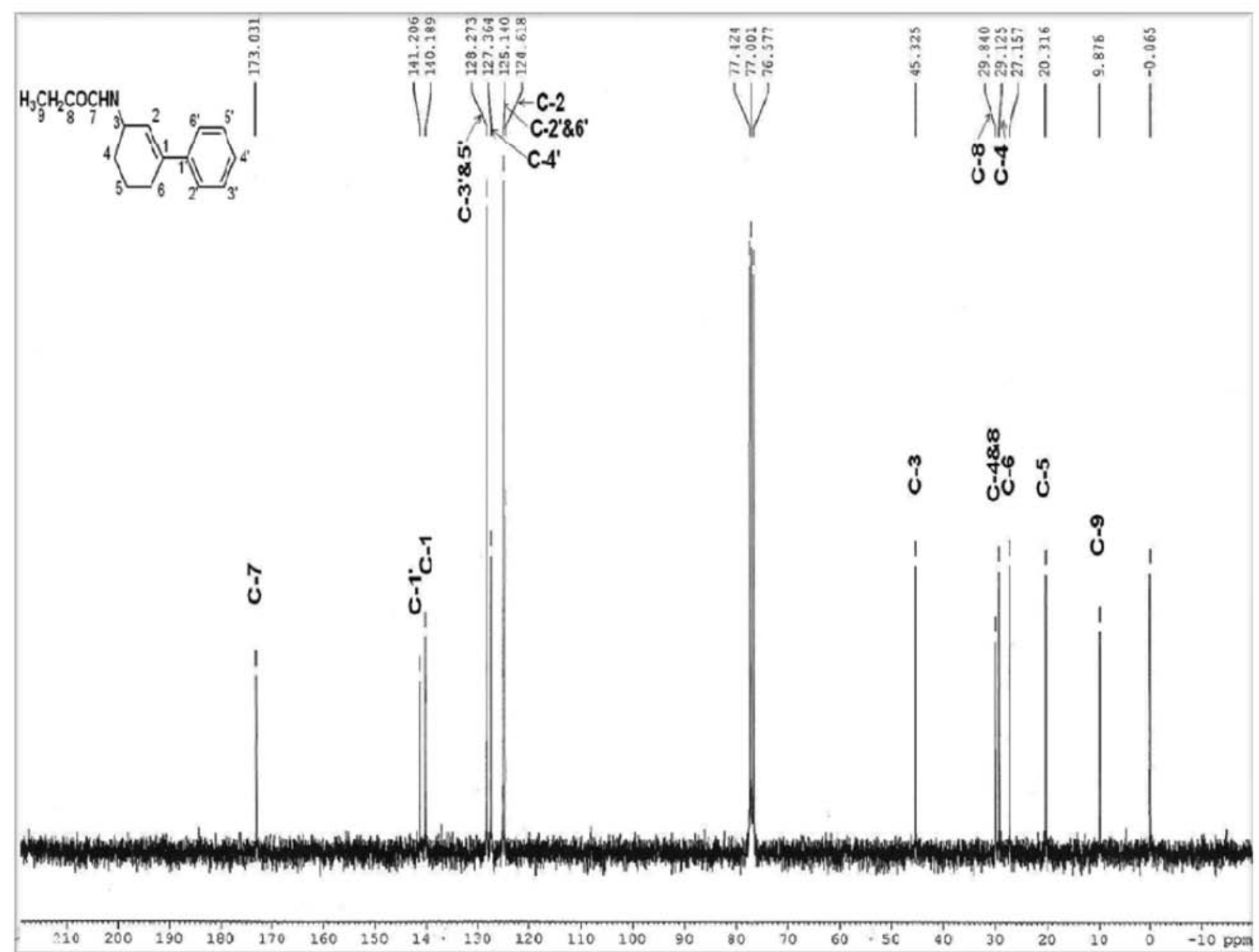

Figure S4. ${ }^{13} \mathrm{C}$ NMR $\left(75 \mathrm{MHz}, \mathrm{CDCl}_{3}\right.$ ) of $\mathrm{N}$-(3-phenylcyclohex-2-enyl)propionamide (Table 1, entry 12). 
<smiles>CCC(=O)NC1C=C(c2ccccc2)CCC1</smiles>
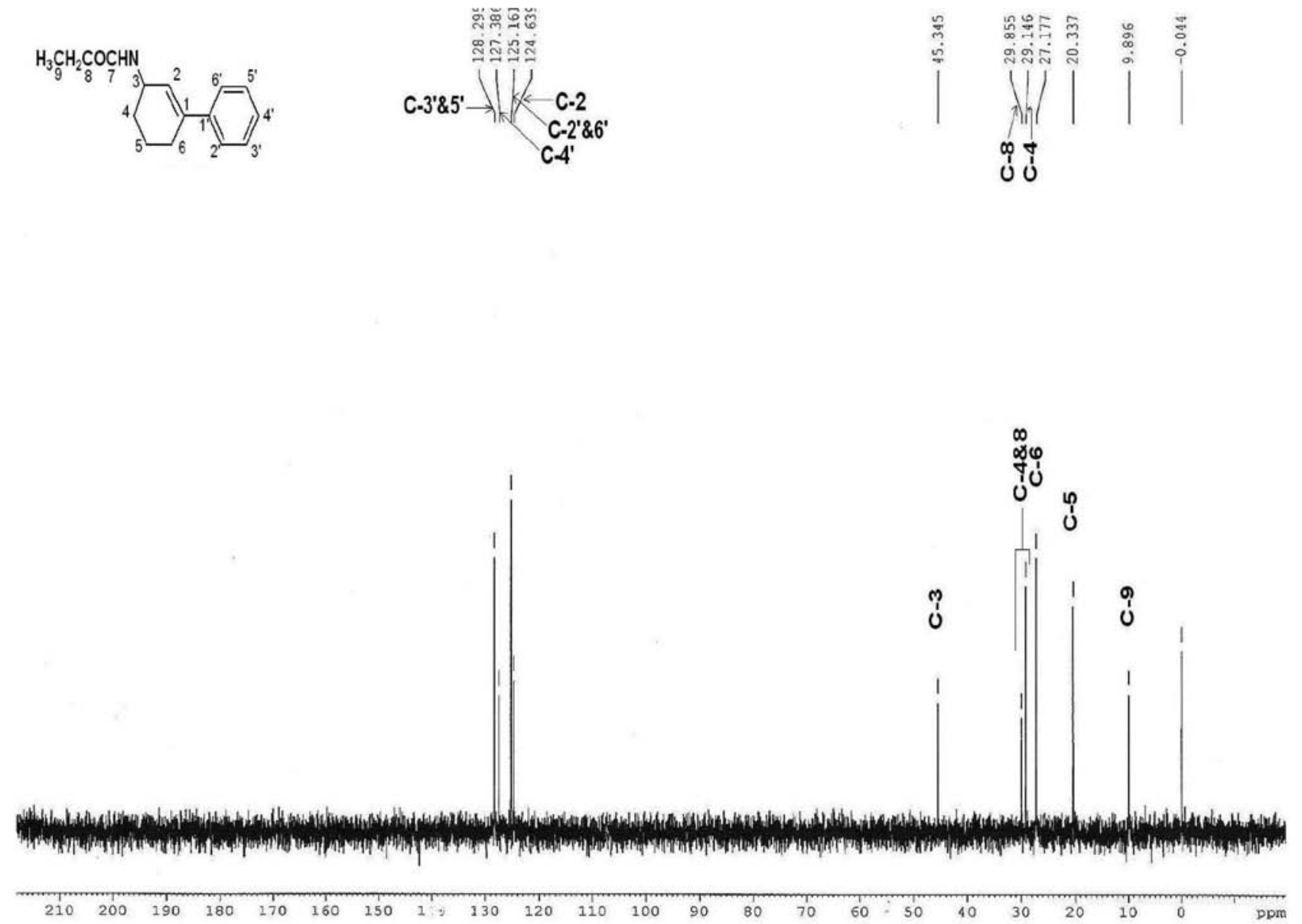

Figure S5. DEPT- 45 of $N$-(3-phenylcyclohex-2-enyl)propionamide (Table 1, entry 12). 
<smiles>CCC(=O)NC1C=C(c2ccccc2)CCC1</smiles>
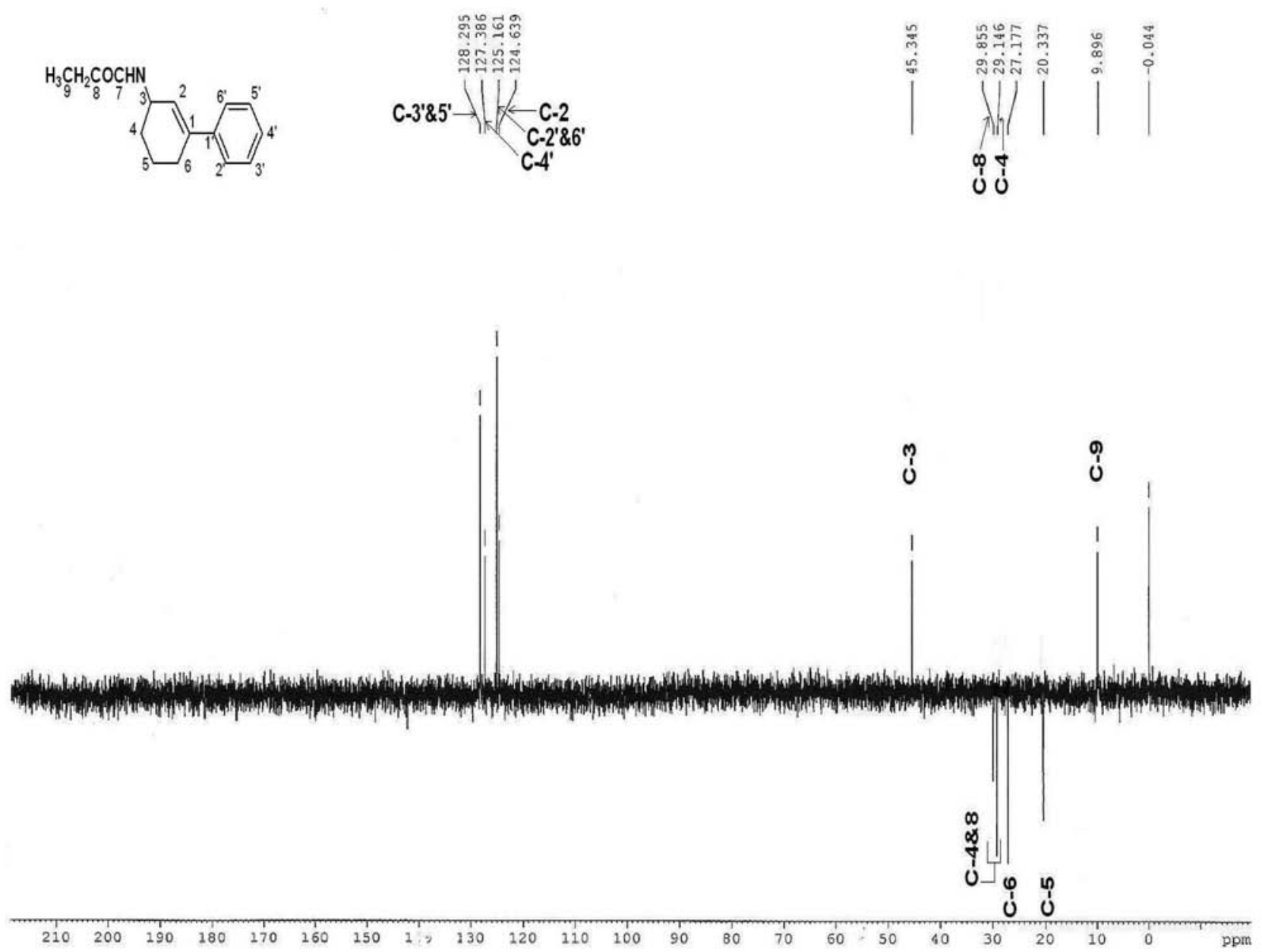

Figure S6. DEPT-135 of $N$-(3-phenylcyclohex-2-enyl)propionamide (Table 1, entry 12). 
<smiles>CCC(=O)NC1C=C(c2ccccc2)CCC1</smiles>

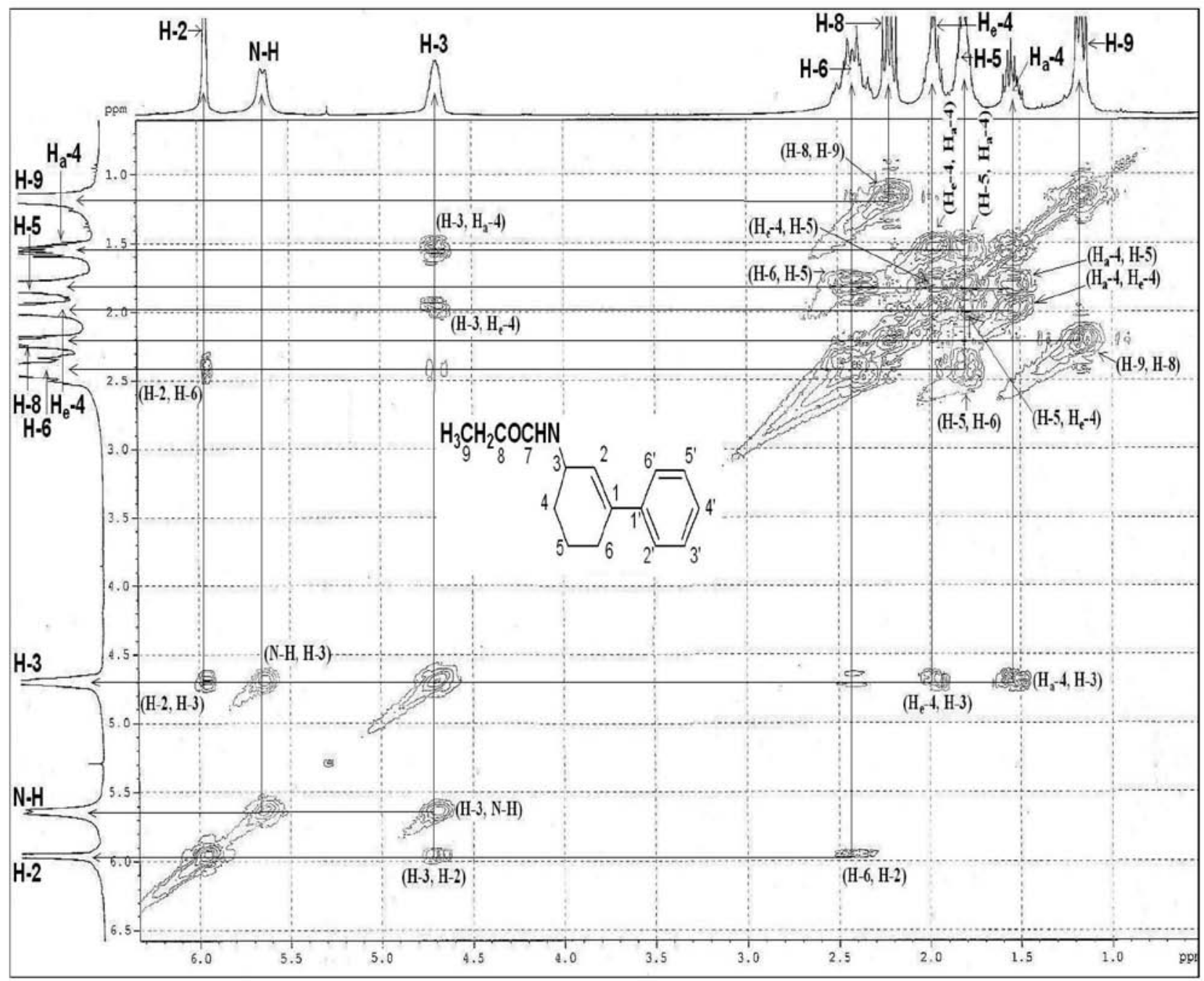

Figure S7. (H, H) COSY of $N$-(3-phenylcyclohex-2-enyl)propionamide (Table 1, entry 12). 
<smiles>CCC(=O)NC1C=C(c2ccccc2)CCC1</smiles>

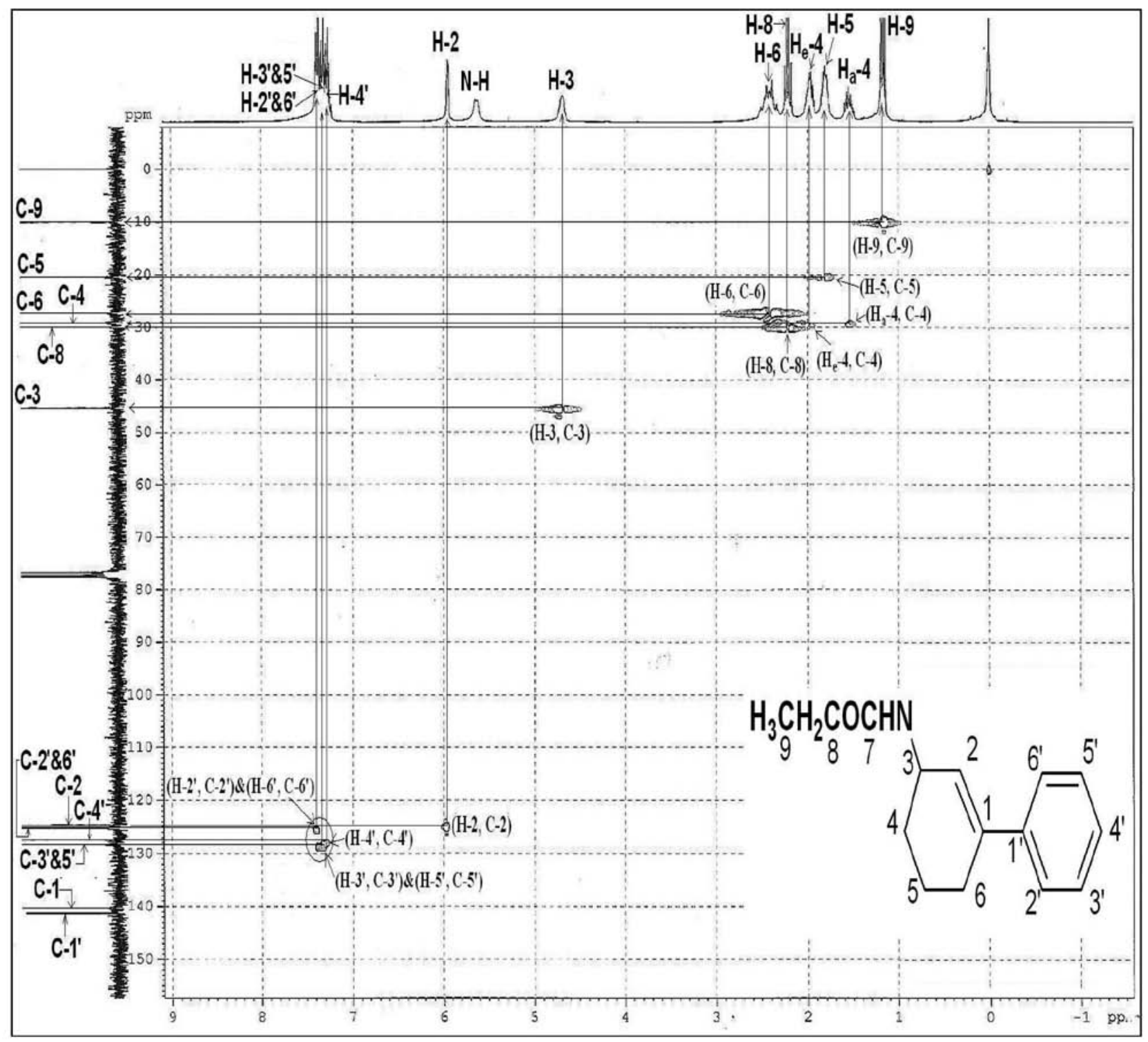

Figure S8. (C, H) COSY of $N$-(3-phenylcyclohex-2-enyl)propionamide (Table 1, entry 12). 
<smiles>CCC(=O)NC1C=C(c2ccccc2)CCC1</smiles>
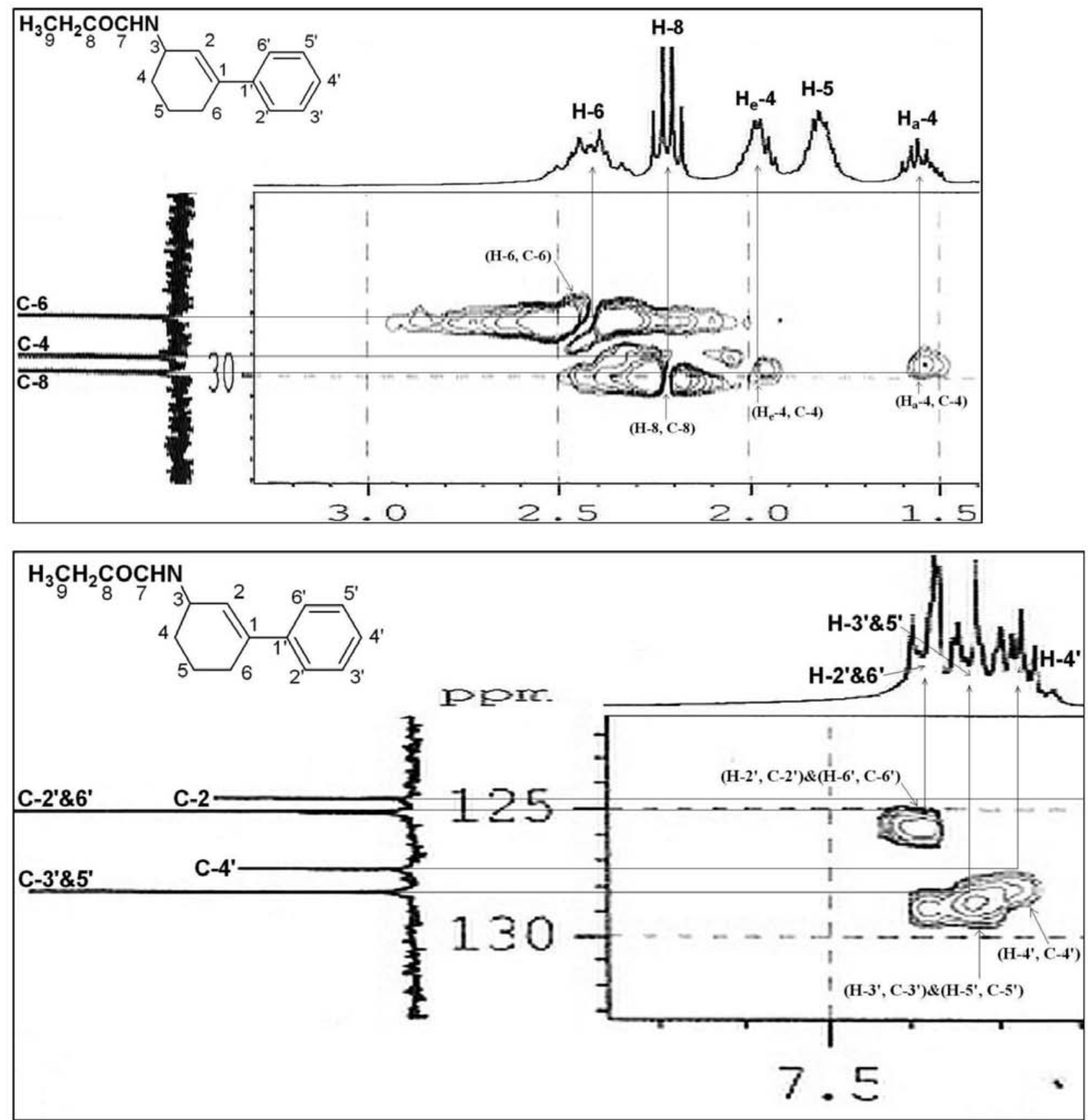

Figure S9. (C, H) COSY of $N$-(3-phenylcyclohex-2-enyl)propionamide (Table 1, entry 12) (expansion). 
<smiles>CCC(=O)NC1C=C(c2ccccc2)CCC1</smiles>

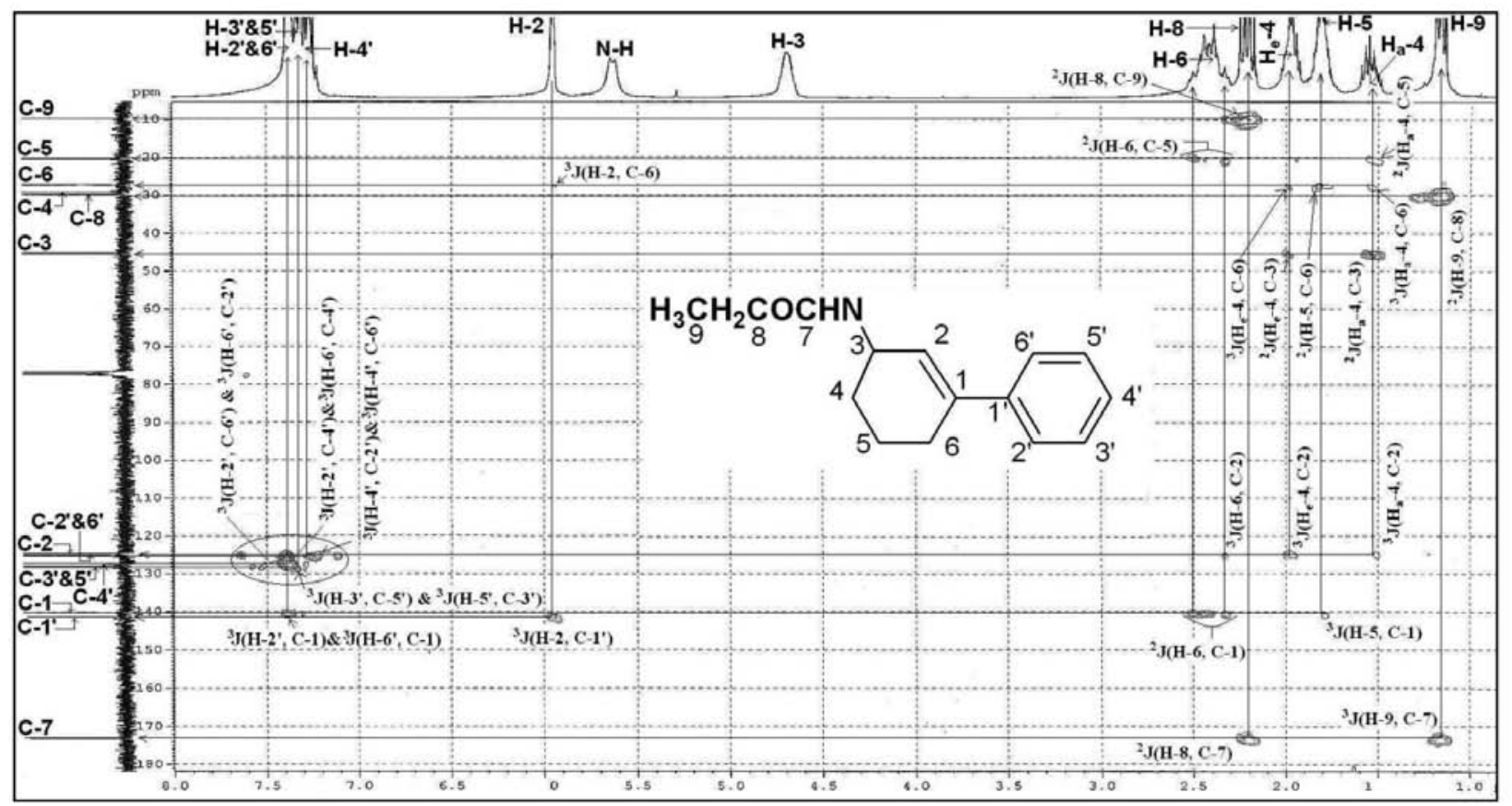

Figure S10. HMBC of $N$-(3-phenylcyclohex-2-enyl)propionamide (Table 1, entry 12).

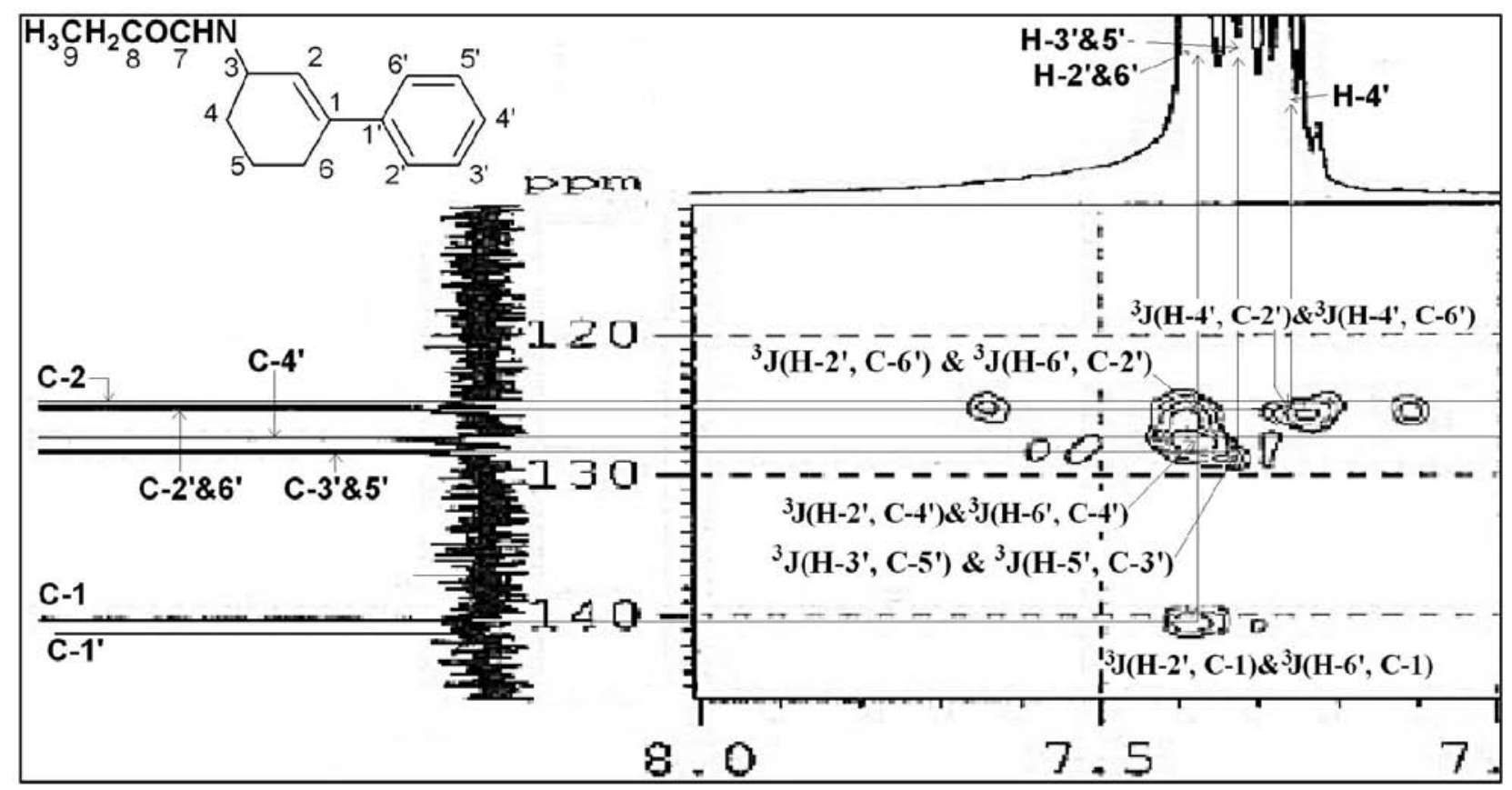

Figure S11. HMBC of $N$-(3-phenylcyclohex-2-enyl)propionamide (Table 1, entry 12) (expansion). 
<smiles>CCCC(=O)NC1C=C(c2ccccc2)CCC1</smiles>

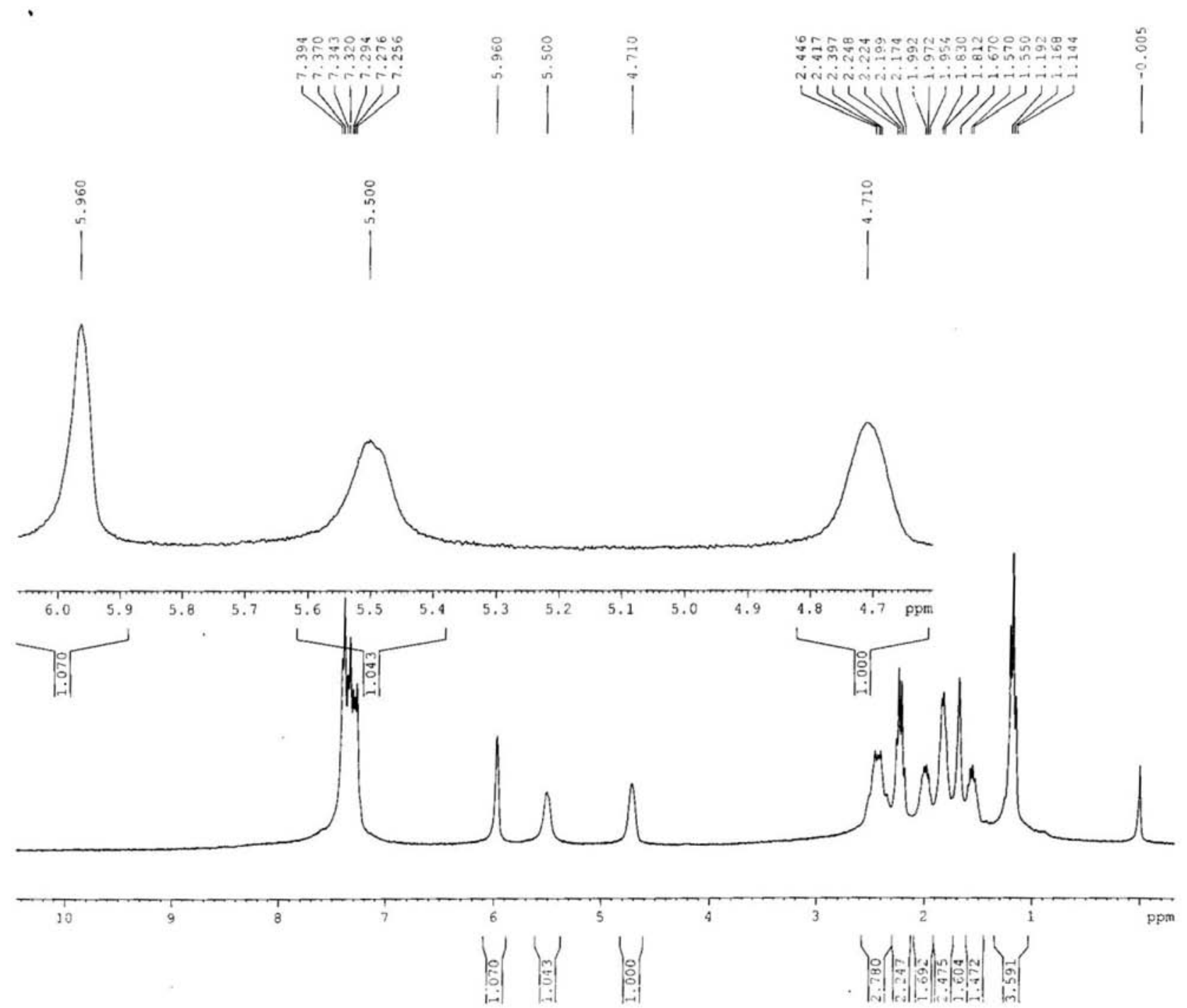

Figure S12. ${ }^{1} \mathrm{H}$ NMR $\left(300 \mathrm{MHz}, \mathrm{CDCl}_{3}\right.$ ) of $\mathrm{N}$-(3-phenylcyclohex-2-enyl)butyramide (Table 1, entry 13). 
<smiles>CCCC(=O)NC1C=C(c2ccccc2)CCC1</smiles>
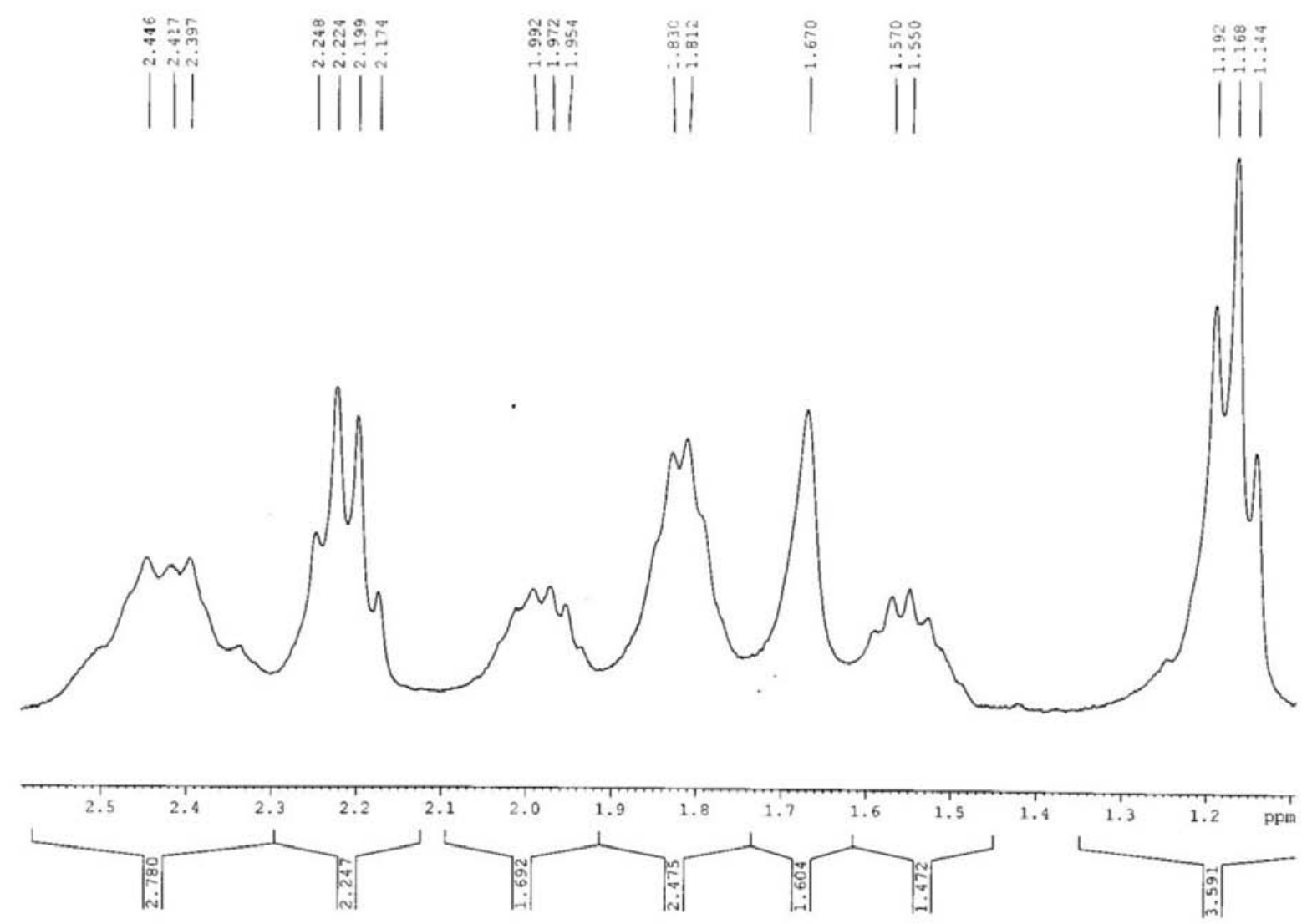

Figure S13. ${ }^{1} \mathrm{H}$ NMR (300MHz, $\mathrm{CDCl}_{3}$ ) of $N$-(3-phenylcyclohex-2-enyl)butyramide (Table 1, entry 13) (expansion). 
Vol. 22, No. 11, 2011

Sathishkumar et al.

$\mathrm{S} 15$
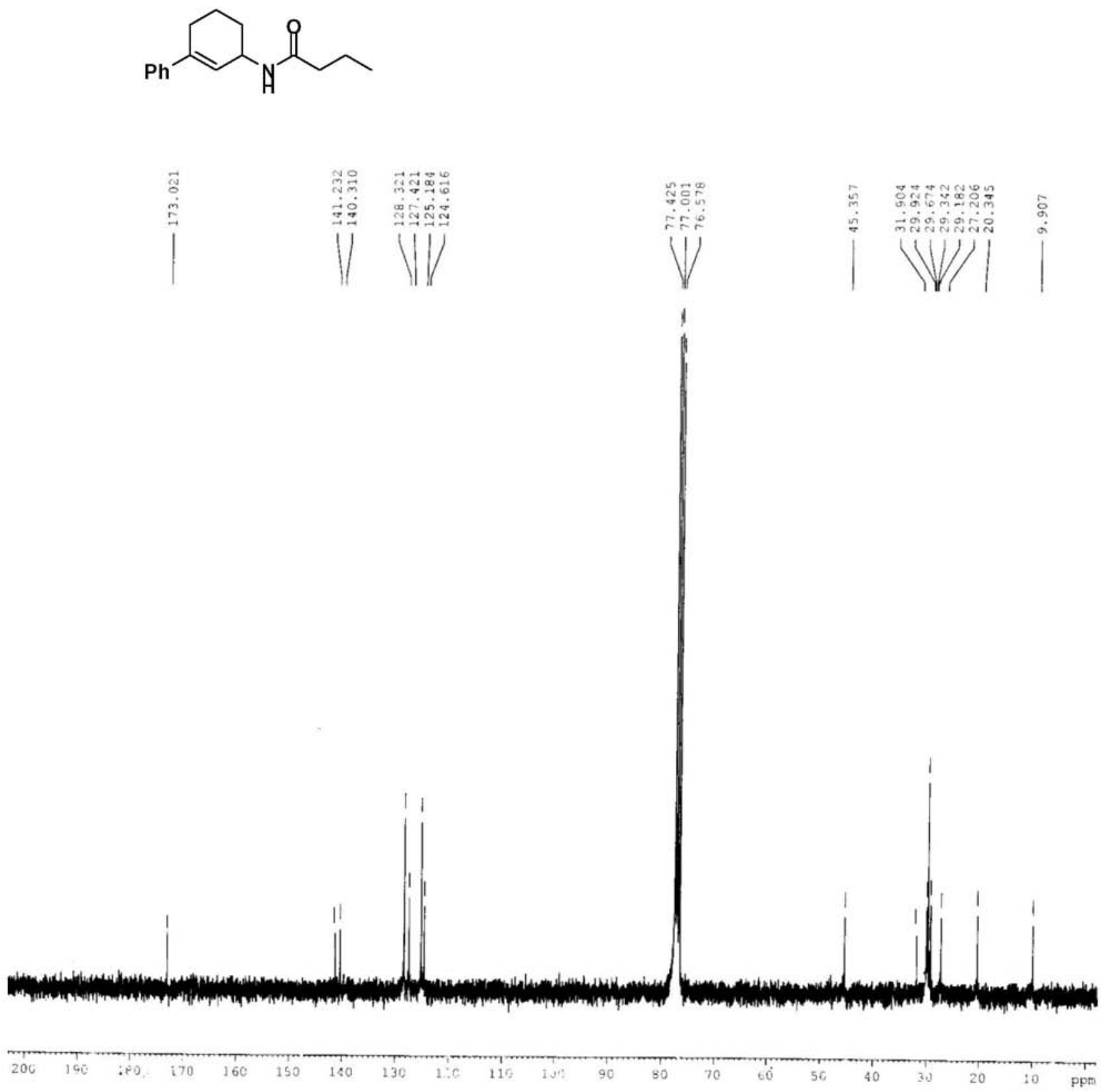

Figure S14. ${ }^{13} \mathrm{C}$ NMR $\left(75 \mathrm{MHz}, \mathrm{CDCl}_{3}\right.$ ) of $N$-(3-phenylcyclohex-2-enyl)butyramide (Table 1, entry 13). 

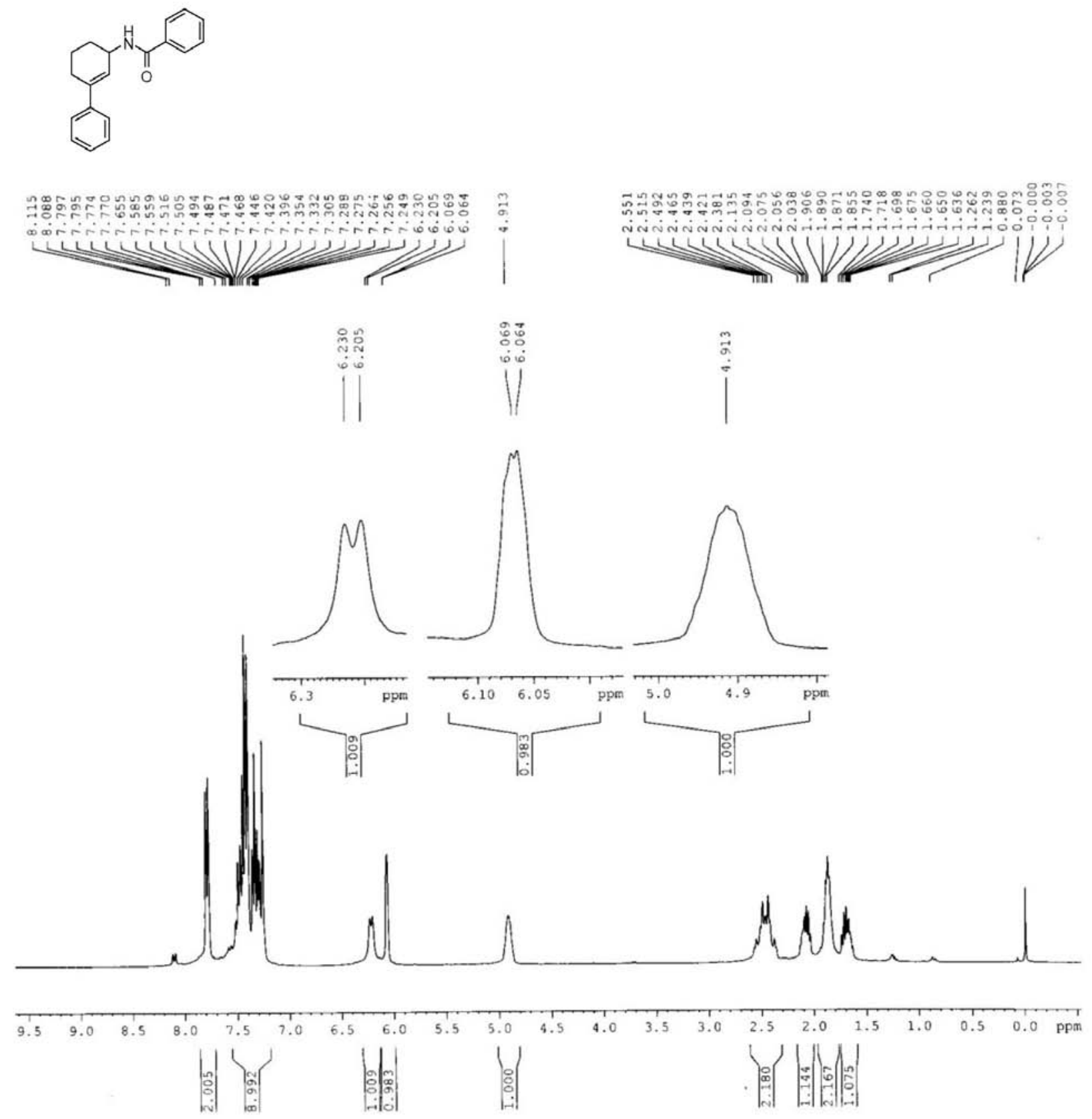

Figure S15. ${ }^{1} \mathrm{H}$ NMR $\left(300 \mathrm{MHz}, \mathrm{CDCl}_{3}\right)$ of $N$-(3-phenylcyclohex-2-enyl)benzamide (Table 1, entry 15). 
<smiles>O=C(NC1C=C(c2ccccc2)CCC1)c1ccccc1</smiles>
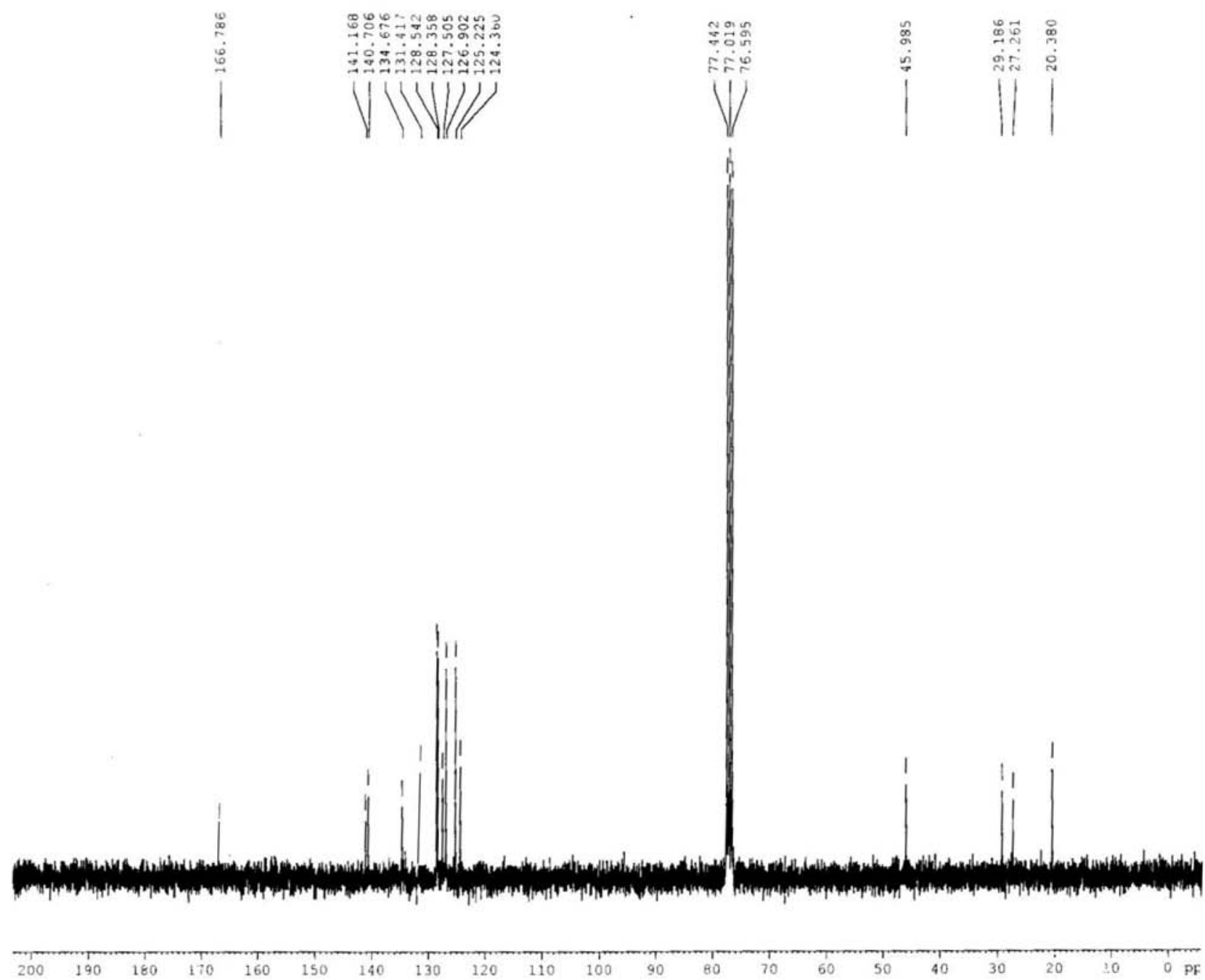

Figure S16. ${ }^{13} \mathrm{C}$ NMR $\left(75 \mathrm{MHz}, \mathrm{CDCl}_{3}\right.$ ) of $\mathrm{N}$-(3-phenylcyclohex-2-enyl)benzamide (Table 1, entry 15). 
<smiles>CC(=O)NC1C=C(c2ccccc2)CCC1</smiles>

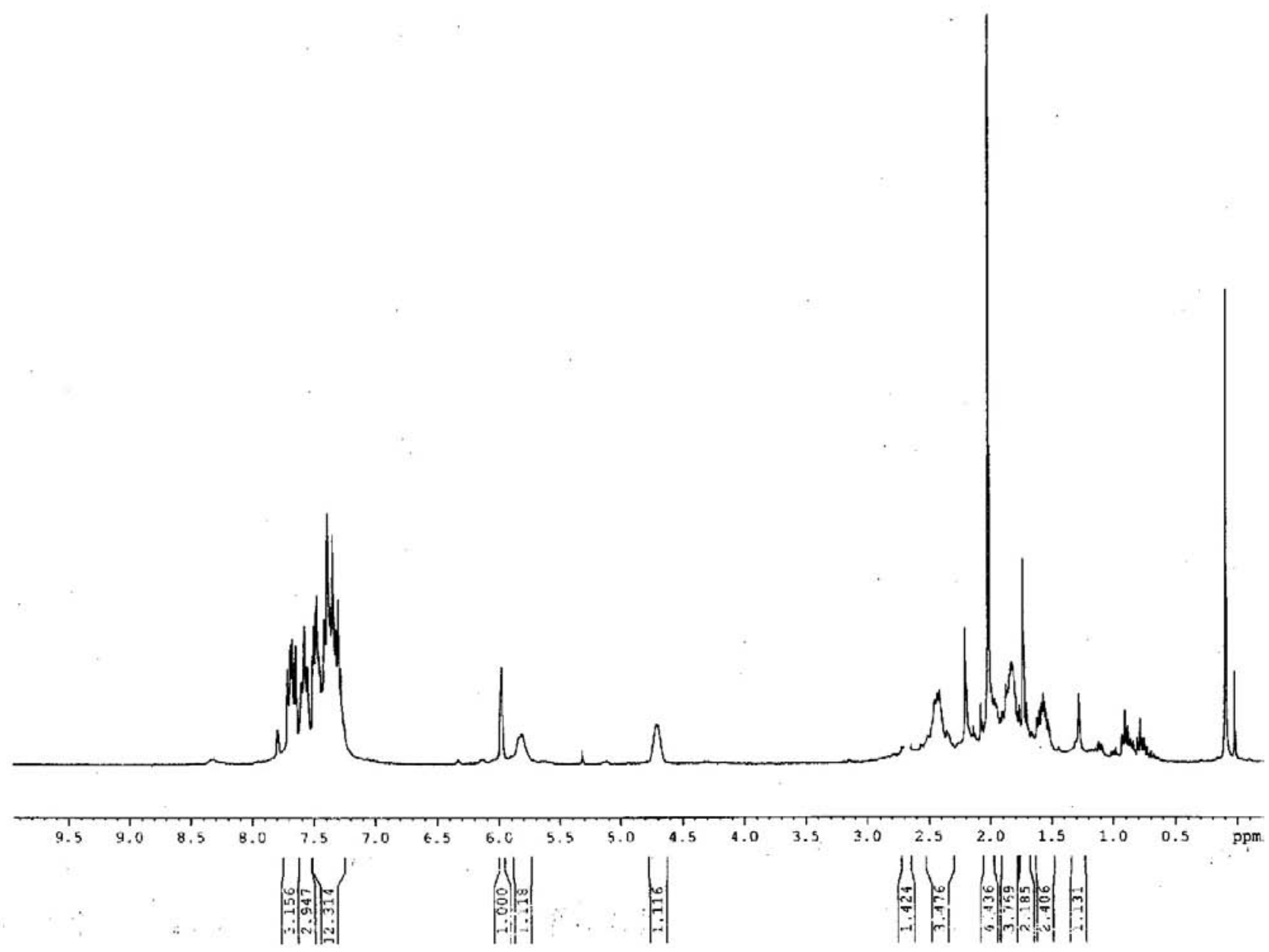

Figure S17. ${ }^{13} \mathrm{C}$ NMR $\left(75 \mathrm{MHz}, \mathrm{CDCl}_{3}\right.$ ) of $\mathrm{N}$-(3-phenylcyclohex-2-enyl)acetamide (Table 1, entry 11 and 14 ). 